\author{
Dr. sc. Mato Arlović, sudac \\ Ustavni sud Republike Hrvatske
}

\title{
PRAVO NA SLOBODU IZRAŽAVANJA MISLI (ustavnopravni okvir i ustavnosudska praksa u Republici Hrvatskoj)
}

\begin{abstract}
UDK: 342.7 (497.5)
Izvorni znanstveni rad

Primljeno: 1. 12.2015.

U radu se obrađuje povezanost i međuodnos slobode kao najviše vrednote ustavnog poretka Republike Hrvatske te najvišeg ideala društva suvremene demokracije i ustavne države prema pravu na slobodu mišljenja i izražavanja misli. Obrađujući taj međuodnos postavlja se namjerava potvrditi teza da je pravo na slobodu mišljenja i izražavanja misli samo jedno (doduše veoma bitno) od ljudskih prava i temeljnih sloboda koje je izvedeno iz slobode kao najviše vrednote i u koju se povratno, funkcionalno vraća te na taj način djeluje na opseg i sadržaj njezina ostvarivanja u odnosu na zamišljeni ideal slobode i zadanu stvarnost. Pravo na slobodu mišljenja i izražavanja misli obrađuje se kao jedan od temeljnih oslonaca za izgradnju demokratskog društva vladavine prava i ustava. U tom kontekstu sagledano je i u funkciji nezaobilaznog uvjeta za ostvarivanje drugih ljudskih prava i temeljnih sloboda. Nadalje ono je sagledano kao pravo koje unutar sebe kroz svoj sadržaj obuhvaća čitav niz drugih prava i sloboda, te se s teorijskog aspekta mora sagledavati kao tzv. pravna konstrukcija. Rad obrađuje ustavno-pravni okvir u Republici Hrvatskoj koji se odnosi na pravo slobode mišljenja i izražavanja misli. U toj obradi posebno se analiziraju subjekti, sadržaj i obilježja prava na slobodu izražavanja misli te praksa Europskog suda za ljudska prava i Ustavnog suda Republike Hrvatske u njegovoj zaštiti.
\end{abstract}

Ključne riječi: sloboda, sloboda mišljenja i izražavanja misli, ustavnopravni okvir, načelna stajališta, ljudska prava i slobode

\section{OPĆENITO O SLOBODI}

Slobodi se u, pravilu, pristupa kao riječi koja „,izražava jedan od najosnovnijih i istovremeno najkontraverznijih pojmova ljudske misli i prakse. “1

Etimološki sloboda se obično određuje kao „1. mogućnost samostalnog, nezavisnog djelovanja, mogućost samoodređenja čovjeka, stanje oprečno postojanju prisile, 2. mogućnost nesmetanog rada u kakvoj oblasti ljudske djelatnosti ... 3. stanje oprečno zatočenju, zatvoru ... 4. povlastica ..."2

Već iz navedenog etimološkog određivanja poimanja slobode i njezinog sadržaja potvrđuje se njezino određenje kao ,jedno od najosnovnijih i istovremeno najkontroverznijih pojmova ljudske misli i prakse.“

1 Politička enciklopedija, Beograd, 1975. g., str. 978.

2 Anić V.; Rječnik hrvatskog jezika, treće, prošireno izdanje, Zagreb, 2000. g., str. 1072. 
Takva složenost i slojevitost pojma slobode nalaže nužnost poimanja njenog pojavnog oblika, sadržaja i mogućeg dosega utjecaja i na međuljudske odnose s različitih aspekata. Riječ je o kategorijalnom pojmu koji se u svom sadržajnom obliku u odnosu između ljudi i njihovih asocijacija i institucija iskazuje kao multidisciplinaran pojam. Zbog tih svojih svojstava sloboda je pojam - objekt - proučavanja filozofa, umjetnika, sociologa, politologa, kulturnjaka, pravnika i mnogih drugih. Ovisno o tome tko je i s kojeg aspekta proučava, njoj se pristupa kao krajnjem cilju - idealu - ljudskog življenja, vrlini, vrednoti, načelu i/ili pravu itd., što dovodi do različitih pristupa u njezinu definiranju. Zbog prirode ovog rada, ilustracije radi spomenut ću one koji definiraju slobodu s ekonomskog, političkog i pravnog aspekta.

I to, prije svega zbog toga što suvremeno pravo sve više tretira slobodu kao

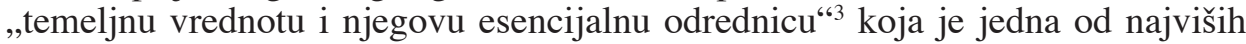
vrednota i na kojoj se temelje suvremeni ustavi i koje su osnova njihova tumačenja. ${ }^{4}$

Drugo; zbog toga što je sloboda, kao temeljna vrednota, jedna od najznačajnijih i najviših vrednota ${ }^{5}$ iz kojih se deriviraju sva ljudska prava i temeljne slobode, pa tako i pravo na pojedine slobode za fizičke i pravne osobe u ukupnosti društvenih odnosa.

Treće; jer je za razumijevanje slobode u pravu neophodno njezino razlikovanje kao političke slobode od metafizičke slobode volje. ${ }^{6}$ Tim više što se termin sloboda u pravu upotrebljava za uređenje konkretnih međuljudskih odnosa onda kada se njime može bolje i preciznije izraziti oblik i sadržaj određenog prava, i to prava kao „ovlaštenja pojedinca koja se moraju respektirati i koja se vrijeđaju činjenjem pogrešnog. "

Četvrto; sloboda kao vrednota uz ostale kao što su npr. jednakost, ravnopravnost (nacionalna, vjerska, spolna itd.), demokracija, predstavnička višestranačka vladavina, poštovanje prava čovjeka, vladavina prava itd., čini osnovicu (barem europskog) zajedničkog nasljeđa i ugaoni kamen za ostvarivanje tradicija, ideala i ciljeva slobodnih ljudi u demokratskom društvu ustavne države u kojem je ljudsko dostojanstvo i pravo na izgradnju i razvoj ljudske osobnosti temeljna vrednota, cilj i zahtjev modernog društva.

Peto; u gore izloženom smislu sloboda kao vrednota jest apsolutna kategorija, no derivirana prava i slobode koje iz nje proizlaze kao subjektivna prava, obveze i odgovornosti, u pravilu nisu i to ne mogu biti. ${ }^{8}$ Naime, potonje slobode kao sustav

3 Pravni leksikon, Zagreb, 2007. g., str. 1468.

4 Takvo opredjeljenje je u članku 3. Ustava Republike Hrvatske, npr. iskazao hrvatski ustavotvorac.

5 Navedenu tezu potvrđuje činjenica da je sloboda kao najviša vrednota ustavnog poretka Republike Hrvatske, u njihovom nabrajanju stavljena na prvo mjesto. Vidjeti pobliže članak 3. Ustava Republike Hrvatske (Narodne novine br. 85/10.).

6 Više o razlikovanju između metafizičke i političke slobode npr. u Političkoj enciklopediji, Beograd, 1975. g., str. 979. te u Pravnom leksikonu, Zagreb, 2007. g., str. 1468. i 1469.

7 Bačić A.; Ustavno pravo Republike Hrvatske, Praktikum, Split, 2006., str. 132.

8 Slobodu kao apsolutnu kategoriju poimam kada je upotrebljavam kao najvišu vrednotu ustavnog 
prava, obveza i odgovornosti oblici su pravnog uređivanja slobode kao vrednote, jer „ljudske slobode mogu biti u sukobu, a kada do njega dođe, slobodu jednog čovjeka treba ograničiti kako bi se sačuvala sloboda onog drugog" - kako je to izrekao jedan sudac Vrhovnog suda Sjedinjenih Američkih Država: „Sloboda kretanja moje šake mora se ograničiti blizinom vaše brade. “9

O navedenim karakteristikama slobode, kao i mnogih drugih koje je uvjetuju, valja voditi računa kod bilo kakvog njezinog određivanja, pa tako i kada se određuje s ekonomskog, političkog i pravnog aspekta. Dakako, vodeći računa da uvjeti koji određuju ili utječu na oblik, sadržaj i doseg slobode nisu istovrsnog djelovanja na nju. Oni se razlikuju ovisno o vremenu i prostoru u kojem se ona promatra, proučava i definira. Samim time valja razumjeti da poimanje slobode u različitim društveno-ekonomskim i političkim sustavima nije istovrsno, osobito polazeći od dominirajućih stajališta koja utvrđuju i prezentiraju nositelji i apologeti vladajuće politike odnosno sustava vlasti i moći. ${ }^{10}$ Poglavito kada ih se analizira i poima polazeći od njezinog sadržaja i uloge u odnosu na upravljače i upravljane kako je oni osjećaju i poimaju kao stvarno ostvarenje i idealnu kategoriju vrednote kojoj teže kao cilju koji žele oživotvoriti odnosno postići, u konkretnim međuljudskim odnosima.

U definiranju ekonomske slobode M. Friedman polazi od teze da je „ona sama sebi svrhom gdje se ona prakticira u organiziranju pretežnog dijela ekonomske aktivnosti“" odnosno „slobode u ekonomskim aranžmanima“ na „slobodnom tržištu“. ${ }^{11}$

Politička sloboda nužno proizlazi iz sustava vladajućih društveno-ekonomskih odnosa, pratii korespondiras vladajućim društveno-ekonomskimi političkopravnim poretkom. U sustavu „kompetitivnog kapitalizma vrsta ekonomske organizacije koja ekonomsku slobodu neposredno pruža, promiče i političku slobodu, odvajajući ekonomsku moć od političke, i na taj način omogućujući jednoj da bude protuteža drugoj“. ${ }^{12}$ Zbog toga „u političkom kontekstu pojam slobode koristi se da bi se naglasila mogućnost izbora koja jest i mora biti podređena pojedincu kao njegovo pravo" ". ${ }^{13}$ Zapravo, polazeći od razlikovanja metafizičkog i političkog poimanja slobode, tradicionalna filozofska i politička teorija utvrđuje

poretka koja je uz ostale vrednote temelj za tumačenje ustava, dok je kao neapsolutnu kategoriju razmatram kada se radi o različitim oblicima prava na slobodu koja su derivirana iz slobode (kao) i/ili drugih vrednota ustavnog poretka. O tome slično Ljubić D., vidjeti njegov rad: „Ustavni pojmovi prava, sloboda, jamstva, načela, mogućnosti i zabrane“, Hrvatska pravna revija, Zagreb, lipanj 2011. g., str. 1.

9 Friedman M., Kapitalizam i sloboda, Globus, Zagreb, 1992. g., str. 36.

10 O uvjetima koji utječu na vrstu i sadržaj slobode više u Političkoj enciklopediji, Beograd, 1975. str. 978-979.

11 Friedman M., Kapitalizam i sloboda, Globus, Zagreb, 1992. g., str. 19-21.

12 Ibid, str. 21., O ekonomskoj i političkoj slobodi i njihovom međuodnosu M. Friedman u navedenom djelu posebno piše u prvom poglavlju „Odnos između ekonomske i političke slobode“ na str. 19-46.

13 Ljubić D., „Ustavi pojmovi prava, slobode, jamstva, načela, mogućnosti i zabrane“, Hrvatska pravna revija, Zagreb, lipanj 2011. g., str. 1. 
razliku između tzv. negativne i pozitivne ideje slobode. Negativna sloboda razumije se kao „sloboda od“, a pozitivna sloboda kao „sloboda za“. ${ }^{14}$ Takav pristup proizlazi između ostalog i zbog toga što je ,sloboda osnovno svojstvo ljudske egzistencije i osnovna ljudska vrijednost koja je objekt" ustavno-pravnog uređenja. „Ona je manifestacija osobnih prava zato što je svako pravno uređenje ljudske slobode moguće samo prema čovjeku kao relativno slobodnom biću." ${ }^{15} \mathrm{U}$ tom smislu u pravu je J. Đorđević kad navodi da se termin sloboda upotrebljava kad se njime bolje može izraziti oblik određenog prava. „Oblik prava određen je mjerom samostalnosti i individualnosti u njegovom ostvarivanju i uživanju. Ako je ta mjera veća i važnija to se pravo naziva slobodom. Svako pravo je istodobno jedan oblik slobode, a time što je štićeno, istovremeno je i pravo kao sloboda."16

Navedeno određenje prava kao oblika određenog (konkretnog) oblika prava na slobodu koji istovremeno izražava i potvrđuje slobodu kao okvirnu i temeljnu vrednotu jest fini oblik dijalektičkog pristupa u poimanju ove problematike primjenjujući teleološku metodu njezinog tumačenja, istu određuje s aspekta odnosa općeg i pojedinačnog sadržaja (kao vrednote) i moguće forme (kroz različite oblike slobode) njegova ispoljavanja.

Takav pristup poimanja slobode, njezina sadržaja i oblika ispoljavanja kao vrednote, ali i kao prava na pojedine slobode u sustavu ljudskih prava i sloboda u ustavnopravnoj teoriji i ustavnopravnoj regulaciji prihvaća moderni konstitucionalizam. ${ }^{17}$ On zato slobodi pristupa kao kondiciji sine qua non svih ljudskih prava i slobode $\mathrm{s}$ jedne strane, a s druge kao jednoj od determinanti države i njezine vlasti, ,na što kod izbora slobode kao prava dovodi diktat osjećaja za razliku između javnog i privatnog“. ${ }^{18} \mathrm{~S}$ treće strane, polazeći od ciljeva, tradicija i ideala koji se žele postići u društvu demokracije, vladavine prava i ustava od nužnih, potrebnih i opravdanih sloboda kao prava i obveza izvedenih iz nje vrednote su koje omogućuju ostvarivanje kako nje same tako i ukupno svih vrednota na kojima je utemeljen ustavnopravni poredak i koje su vrijednosna osnova za izgradnju društvene i državne zajednice prava, sloboda i demokracije za slobodne, ravnopravne i pred pravima jednake članove ljudske zajednice bez ikakvog oblika diskriminacije po bilo kojoj osobini ili svojstvu pojedinca kao ljudskog bića. Naravno, vodeći računa o realnosti koja proizlazi iz povijesnog i sociološkog, kulturnog nasljeđa, stupnju društveno-ekonomskog i ukupnog društvenog razvoja za svaku konkretnu zemlju. $U$ tom pogledu mogu postojati stanovite razlike između pojedinih odabranih oblika sloboda kao prava kako po broju i opsegu tako i po mogućnostima i oblicima njihovog ograničenja. Uvijek vodeći računa o razmjernom odnosu u zaštiti i ostvarivanju kako javnog tako i

14 Pravni leksikon, Zagreb, 2007. g., str. 1467.

15 Kao u fusnoti 13, str. 3.

16 Đorđević J., „Politički sistem“, Beograd, 1977. g., str. 963.

17 O pojmu modernog konstitucionalizma vidjeti primjerice kod Sweet, A. S., u "Ustavi i sudska vlast", objavljeno u Carmani D., Komparativna politika, Zagreb, 2013. g., str. 164. ili kod Bačić, P., Konstitucionalizam i sudski aktivizam, Split, 2010. g., str. 78.

18 Pravni leksikon, Zagreb, 2007. g., str. 1467. 
privatnog interesa, uz neupitnost postojanja onih prava na slobode koje jamče poštovanje i provedbu slobode i drugih vrednota tog ustavnog poretka u cjelini ${ }^{19}$ i njime prihvaćenih, propisanih i zajamčenih ljudskih prava i sloboda te prava $\mathrm{i}$ sloboda manjina i njihovih pripadnika kao jednog od nezaobilaznih elemenata suvremenog konstitucionalizma.

Među njih, svakako, ulaze slobode mišljenja i izražavanja misli, slobode savjesti i vjeroispovijesti, slobode javnog okupljanja, sloboda udruživanja, sloboda kretanja, sloboda ugovaranja, sloboda poduzetništva i razmjene, sloboda osnivanja političkih stranaka, sloboda izbora itd.

\section{UKRATKO O PRAVU NA SLOBODU IZRAŽAVANJA}

Pravo na slobodu izražavanja, prema nekim autorima ${ }^{20}$ razvilo se i proizašlo je iz prava na slobodu govora, a „,nastalo je kao jamstvo onima koji misle drugačije od vlasti ili drugačije od većine svojih sugrađana“. ${ }^{21}$ Pravo na slobodu izražavanja jedan je (moglo bi se reći glavni) od kamena temeljaca na kojima počiva razvoj suvremene moderne demokracije, ostvarivanja tradicija, ciljeva i ideala slobodnog društva, slobodnih i ravnopravnih pojedinaca u slobodnoj i demokratskoj društvenoj i državnoj zajednici vladavine prava i ustava. Istovremeno ona je uz to i „nužna pretpostavka uživanja brojnih drugih prava i sloboda proglašenih u Konvenciji“. ${ }^{22}$ Zapravo, u politološkim pristupima pod slobodom izražavanja općenito se smatra ono što je u temeljima drugih temeljnih sloboda (i prava, op. A.), kao što su pravo glasa, osnivanje političkih stranaka, razmjena političkih ideja i kontrola javnih dužnosnika. ${ }^{23}$

Poznati liberal John Stuart Mill smatrao je da sloboda govora nije bitna i nužna samo zato što svatko ima pravo na slobodu izražavanja, već i zato što zajednica u kojoj živimo ima pravo čuti naša razmišljanja. ${ }^{24}$ Čini se da, polazeći od takvog Millovog promišljanja, V. Alaburić izvodi zaključak da je „individualno ljudsko pravo na slobodu izražavanja prošireno društveno-kolektivnim odnosno

19 O tome da je Ustav cjelina i da mu se kao cjelini mora pristupati, zauzeo je stajalište i Ustavni sud Republike Hrvatske utvrđujući: „Ustav čini jedinstvenu cjelinu. Njemu se ne može pristupati na način da se iz cjeline odnosa koji se njime ustrojavaju izvlači jedna odredba pa se ona ovako tumači zasebno i mehanički neovisno o svim ostalim vrijednostima koje su Ustavom zaštićene. Ustav posjeduje unutarnje jedinstvo i značenje pojedinog dijela vezano je uz sve ostale odredbe. Promatra li ga se jedinstveno, Ustav odražava pojedine odredbe. Stoga se ni jedna ustavna odredba ne može izvući iz konteksta i samostalno interpretirati. Drugim riječima, svaka pojedina ustavna odredba uvijek se mora tumačiti u skladu s najvišim vrednotama ustavnog poretka koje su temelj za tumačenje Ustava“ (Rješenje Ustavnog suda Republike Hrvatske broj: U-I-3789/2003. i dr. od 8. prosinca 2010., Narodne novine br. 142/10.).

20 Tako npr. Smerdel, B., vidjeti njegovu knjigu Ustavno uređenje europske Hrvatske, Zagreb, 2013. g., str. 320-325.

21 Ibiden, str. 320.

22 Gomien, D., Europska konvencija o ljudskim pravima, Zagreb, 2007. g., str. 167. 362.

23 Norris, P., „Politička komunikacija“, u Caramani, D., Komparativna politika, Zagreb, 2013., str.

24 John Stuart Mill, O slobodi, Zagreb, 1918. g. 
funkcionalnim demokratskim pravom građana da budu informirani odnosno pravom javnosti da zna". ${ }^{25}$ Zbog toga ukazuje na dvodimenzionalnost prava na slobodu izražavanja, prvo kao temeljnog osobnog prava, a drugo kao kolektivnog političkog prava javnosti odnosno građana. I to zato što po njenom mišljenju „upravo ta dvostrukost čini ga jednim od najznačajnijih prava na indeksu svih ljudskih prava i sloboda. Sloboda izražavanja, naime, nije samo conditio sine qua non (nezaobilazni uvjet, op. A.) intelektualnog i duhovnog razvitka svakog pojedinca kao osobe, nego i temeljni uvjet opstanka svih njih zajedno kao demokratske zajednice. “26 Slažem se s izloženom konstatacijom V. Alaburić, iako je smatram djelomice preuskom, zapravo nedovoljno obuhvatnom. Naime, ako je pravo na slobodu izražavanja misli bitna pretpostavka realizacije svih ljudskih prava i temeljnih sloboda, koji su potrebni za stvaranje ljudskog dostojanstva ${ }^{27}$ jer čine samu njegovu esenciju, te su potvrda razvoju i izgradnji osobnosti svakog ljudskog bića kao pripadnika društvene zajednice, tada je ono ne samo nezaobilazni uvjet već sama bit osobnosti drugih sadržaja ljudskosti i ljudskog dostojanstva svakog čovjeka, bez diskriminacije po bilo kojoj osnovi ili njegovoj osobini.

Zbog toga nije jednostavno ni lako odrediti što jest i što bi trebalo biti pravo na slobodu izražavanja misli.

Osobno smatram da je tome moguće prići tek nakon sagledavanja ustavnopravnog okvira i njegove analize u dijelu koji se odnosi na ustavom konkretno utvrđeno i zajamčeno pravo na slobodu izražavanja.

Upravo tako ću nastojati postupiti u pristupu daljnjeg proučavanja prava na slobodu izražavanja u ustavnopravnom poretku Republike Hrvatske. Tim više što je hrvatski ustavotvorac u izradi i donošenju svog Ustava prihvatio model koji proizlazi iz teorijskog koncepta modernog (suvremenog) konstitucionalizma.

25 Alaburić, V.; Sloboda izražavanja u Republici Hrvatskoj, Priručnik o slobodi riječi, (COLIVER, Sandra, DARBSHIRE, Helen i BOŠNJAK, Mario ur.), Article 19, London, i Press Data, Zagreb, 1998. g., str. 7.

26 Ibiden, str. 6-7.

27 Ovdje se na ljudsko dostojanstvo referira onako kako ga poima Temeljni zakon Njemačke u članku 1., i njegovoj osnovi za sva ljudska prava i slobode koje iz njega proizlaze i u njega se kroz doprinos njegovom ostvarenju funkcionalno vraćaju nakon stvarnog ostvarenja u društvenoj zajednici. 


\section{USTAVNO-PRAVNI OKVIR PRAVA NA SLOBODU IZRAŽAVANJA MISLI}

\section{Opći pristup}

Sukladno dugovječnoj tradiciji i prihvaćenom teorijskom konceptu modernog konstitucionalizma normativnog uređenja ustavnodemokratske države, u Republici Hrvatskoj, kao i u većini demokratskih ustavnih država, sloboda se razumijeva kao pravo da se ne čini ništa što šteti drugome ili, još točnije, da se može činiti i koristiti sa svime onim što zakon ne zabranjuje. Republika Hrvatska je slobodu prihvatila kao jednu od najviših vrednota svog ustavnog poretka te, uz ostale najviše vrednote, kao osnovu za tumačenje Ustava Republike Hrvatske. ${ }^{28}$

Polazeći od najviših vrednota ustavnog poretka, a posebice od slobode kao jedne od njih, Ustav Republike Hrvatske u svom članku 14., stavku 1. propisuje: „Svatko u Republici Hrvatskoj ima prava i slobode, neovisno o njegovoj rasi, boji kože, spolu, jeziku, vjeri, političkom ili drugom uvjerenju, nacionalnom ili socijalnom podrijetlu, imovini, rođenju, naobrazbi, društvenom položaju ili drugim osobinama“. ${ }^{29}$

Pored njih to su i odredbe Ustava Republike Hrvatske koje se odnose na mogućnost ograničavanja ljudskih prava i sloboda „da bi se zaštitila sloboda i prava drugih ljudi te pravni poredak, javni moral i zdravlje“, ${ }^{30}$ zatim mogućnost ograničavanja sloboda i prava zajamčenih Ustavom „u doba ratnog stanja ili neposredne ugroženosti neovisnosti i jedinstvenosti države te velikih prirodnih nepogoda“. ${ }^{31}$

28 Najviše vrednote ustavnog poretka Republike Hrvatske propisane su člankom 3. njezinog Ustava (Narodne novine br. 85/10.), koji glasi: „Sloboda, jednakost, nacionalna ravnopravnost i ravnopravnost spolova, mirotvorstvo, socijalna pravda, poštivanje prava čovjeka, nepovredivost vlasništva, očuvanje prirode i čovjekova okoliša, vladavina prava i demokratski višestranački sustav najviše su vrednote ustavnog poretka Republike Hrvatske i temelj za tumačenje Ustava“.

29 Vidjeti Ustav Republike Hrvatske (Narodne novine br. 85/10.).

30 Vidjeti članak 16., stavak 1. Ustava Republike Hrvatske (Narodne novine br. 85/10.), koji glasi: „Slobode i prava mogu se ograničiti samo zakonom da bi se zaštitila sloboda i prava drugih ljudi te pravni poredak, javni moral i zdravlje“".

31 Navedenu ustavnopravnu situaciju regulira Ustav Republike Hrvatske (Narodne novine br. 85/10.). u svom članku 17.

\section{Članak 17}

U doba ratnog stanja ili neposredne ugroženosti neovisnosti i jedinstvenosti države, te velikih prirodnih nepogoda pojedine slobode i prava zajamčena Ustavom mogu se ograničiti. O tome odlučuje Hrvatski sabor dvotrećinskom većinom svih zastupnika, a ako se Hrvatski sabor ne može sastati, na prijedlog Vlade, i uz supotpis predsjednika Vlade, predsjednik Republike.

Opseg ograničenja mora biti primjeren naravi pogibelji, a za posljedicu ne može imati nejednakost osoba s obzirom na rasu, boju kože, spol, jezik, vjeru, nacionalno ili socijalno podrijetlo.

Niti u slučaju neposredne opasnosti za opstanak države ne može se ograničiti primjena odredbi ovoga Ustava o pravu na život, zabrani mučenja, surovog ili ponižavajućeg postupanja ili kažnjavanja, o pravnoj određenosti kažnjivih djela i kazni, te o slobodi misli, savjesti i vjeroispovijedi.“ 
Navedene su odredbe zajednička osnova za tumačenje i primjenjuju se u regulaciji, ostvarivanju i zaštiti svih ljudskih prava i sloboda, pa tako i na različite oblike ustavom utvrđenih prava na slobodu kao subjektivnih prava, obveza i odgovornosti pravnih subjekata i u njihovim međusobnim odnosima u društvu.

U tom smislu one su kao vrednote, načela i zajedničke odredbe svojevrsni neizravni izvor kao dio ustavno-pravnog okvira kojim se uređuje i sloboda izražavanja, ali su nezaobilazne kako u njezinoj ustavnopravnoj regulaciji tako i u ostvarivanju odnosno zaštiti prava na slobodu izražavanja i/ili njihovog ograničavanja. ${ }^{32}$

Međutim, sloboda izražavanja je u sklopu ustavnopravnog poretka uređena i pravnim normama koje su izravni izvor njezine regulacije.

No, prije no što kažem nekoliko riječi o njima, valja ukazati na neke od specifičnosti njezina ustavnopravnog uređivanja, zaštite i ostvarivanja koje proizlaze iz prihvaćanja monističkog načela u odnosima međunarodnog i unutarnjeg prava. Naime, Republika Hrvatska, kao i niz drugih europskih država, u svom je ustavnopravnom poretku prihvatila ova načela i pravno ih razradila u svom Ustavu. Tako Ustav Republike Hrvatske u članku 141. propisuje: „Međunarodni ugovori koji su sklopljeni i potvrđeni u skladu s Ustavom i objavljeni, a koji su na snazi, čine dio unutarnjega pravnog poretka Republike Hrvatske, a po pravnoj su snazi iznad zakona. Njihove se odredbe mogu mijenjati ili ukidati samo uz uvjete i na način koji su u njima utvrđeni, ili suglasno općim pravilima međunarodnog prava." Jedan od takvih međunarodnih ugovora je Europska konvencija za zaštitu ljudskih prava i temeljnih sloboda (dalje u tekstu: Europska konvencija). Ona po prirodi predmeta koje regulira uz ostalo sadrži i odredbu o pravnom uređenju slobode izražavanja. ${ }^{33}$

Druga specifičnost proizlazi iz činjenice da je Republika Hrvatska kao članica Vijeća Europe i Europske unije prihvatila supsidijarnu nadležnost Europskog suda za ljudska prava u Strasbourgu (dalje u tekstu: ESLJP) u sudskoj zaštiti ljudskih prava i sloboda. Uz tu nadležnost Republika Hrvatska se (kao i druge članice) obvezala na poštovanje i provedbu ne samo odluka ESLJP-a već i njegovih zauzetih stajališta iskazanih u obrazloženjima odluka iz pojedinih konkretnih slučajeva, neovisno o tome jesu li su konkretni slučajevi iz Republike Hrvatske ili iz bilo koje druge članice Vijeća Europe. Shodno tome i stajališta ESLJP-a su postala izvorom ustavnopravnog okvira reguliranja i zaštite ljudskih prava i sloboda općenito, pa i slobode izražavanja konkretno.

32 Više o ograničenjima ljudskih prava i sloboda, pa tako i prava na slobodu izražavanja u autorovom radu: „Ustav Republike Hrvatske osnova društva ravnopravnih ljudi, sigurnosti i stabilnosti“, referat podnesen na Međunarodnoj konferenciji Ustav: jedinstvo ljudi, stabilnosti i prosperiteta, u povodu obilježavanja dvadesete godišnjice donošenja Ustava Republike Kazahstana, održanoj u Astani 28. i 29. kolovoza 2015. g.

33 Konvencija za zaštitu ljudskih prava i temeljnih sloboda s pripadajućim Protokolima objavljena je u Narodnim novinama - Međunarodni ugovori br. 18/97., 6/99. i 8/99. U Republici Hrvatskoj primjenjuje se od 1997. kada je Hrvatska primljena u punopravno članstvo Vijeća Europe. 
Slično, gotovo je identična situacija i u pogledu odluka i zauzetih stajališta u njihovim obrazloženjima koje donosi Ustavni sud Republike Hrvatske. No, o utjecaju na reguliranje, ostvarivanje i zaštitu prava na slobodu izražavanja koji proizlazi iz jurisprudencije ESLJP-a te Ustavnog suda Republike Hrvatske, bit će više riječi u daljnjem tekstu ovog rada.

Dakako, ustavom utvrđeno pravo na slobodu izražavanja kao jedno od ljudskih prava i temeljnih sloboda razrađuje se organskim zakonima u skladu s Ustavom.

\section{Ustavnopravni okvir prava na slobodu izražavanja}

Sukladno prethodno iskazanom, možemo zaključiti da ustavnopravni okvir koji se odnosi na direktno ustavno, konvencijsko uređenje i zakonsku razradu ostvarivanja i zaštite slobode izražavanja kao subjektivnog prava čine:

a) odgovarajuće odredbe Ustava Republike Hrvatske,

b) odgovarajuća odredba Europske konvencije,

c) odgovarajući zakoni kojima se razrađuje pravo na slobodu izražavanja te

d) zauzeta stajališta u konkretnim predmetima ESLJP-a te Ustavnog suda Republike Hrvatske.

a.a.) Ustav Republike Hrvatske pravo na slobodu izražavanja direktno (izravno) regulira odredbom članka 38. On glasi:

„Jamči se sloboda mišljenja i izražavanja misli.

Sloboda izražavanja misli obuhvaća osobito slobodu tiska i drugih sredstava priopćavanja, slobodu govora i javnog nastupa i slobodno osnivanje svih ustanova javnog priopćavanja.

Zabranjuje se cenzura. Novinari imaju pravo na slobodu izvještavanja i pristupa informaciji.

Jamči se pravo na pristup informacijama koje posjeduju tijela javne vlasti. Ograničenja prava na pristup informacijama moraju biti razmjerna naravi potrebe za ograničenjem u svakom pojedinom slučaju te nužna u slobodnom i demokratskom društvu, a propisuju se zakonom.

Jamči se pravo na ispravak svakomu komu je javnom viješću povrijeđeno Ustavom i zakonom utvrđeno pravo.“"34

34 Napominjemo da je članak 38. Ustava Republike Hrvatske nadopunjen novim stavkom 4., 2010. godine nakon četvrte promjene. 
b.b.) Slično, sadržajno gotovo u cijelosti kompatibilno ustavnoj regulaciji prava na slobodu izražavanja, ${ }^{35}$ to pravo u svom članku 10. propisuje Europska konvencija. On glasi:

„1. Svatko ima pravo na slobodu izražavanja. To pravo obuhvaća slobodu mišljenja i slobodu primanja i širenja informacija i ideja bez miješanja javne vlasti i bez obzira na granice. Ovaj članak ne sprečava države da podvrgnu režimu dozvola ustanove koje obavljaju djelatnosti radija ili televizije te kinematografsku djelatnost.

2. Kako ostvarivanje tih sloboda obuhvaća dužnosti i odgovornosti, ono može biti podvrgnuto formalnostima, uvjetima, ograničenjima ili kaznama propisanim zakonom, koji su u demokratskom društvu nužni radi interesa državne sigurnosti, teritorijalne cjelovitosti ili javnog reda i mira, radi sprečavanja nereda ili zločina, radi zaštite zdravlja ili morala, radi zaštite ugleda ili prava drugih, radi sprečavanja odavanja povjerljivih informacija ili radi očuvanja autoriteta i nepristranosti sudbene vlasti.“"

c.c.) Polazeći od članka 83., stavka 2. Ustava Republike Hrvatske, ${ }^{36}$ ustavom zajamčeno pravo na slobodu izražavanja razrađeno je organskim zakonima. Sukladno monističkom načelu i ustavom utvrđenom hijerarhijskom rasporedu u odnosima između Ustava i Europske konvencije, ${ }^{37}$ organski zakoni razradili su dosljedno pravo na slobodu izražavanja u skladu s odredbom članka 38. Ustava Republike Hrvatske, ali i članka 10. Konvencije, te dakako u skladu s drugim odredbama Ustava koje se odnose na pravne odnose u vezi s ovom problematikom.

Riječ je o sljedećim organskim zakonima:

- Zakon o medijima (Narodne novine br. 59/04., 84/11. i 84/13.);

- Zakon o javnom priopćavanju (Narodne novine br. 69/03. - pročišćeni tekst);

35 Do sličnosti i značajne kompatibilnosti članka 38. Ustava Republike Hrvatske i članka 10. Europske konvencije dolazi tek nakon dopune novim stavkom 4. članka 38. Ustava koji je u njega ugrađen provođenjem četvrte promjene Ustava 2010. Dodatno bi se moglo reći da je ta dopuna rađena u skladu $\mathrm{s}$ člankom 10. Europske konvencije te u skladu sa stajalištima koja su o tim pitanjima zauzeli ESLJP i Ustavni sud Republike Hrvatske. O tome nešto više naknadno.

36 Članak 83., stavak 2. Ustava Republike Hrvatske (Narodne novine br. 85/10.) glasi: „Zakone (organski zakoni) kojima se razrađuju Ustavom utvrđena ljudska prava i temeljne slobode, izborni sustav, ustrojstvo, djelokrug i način rada državnih tijela te ustrojstvo i djelokrug lokalne i područne (regionalne) samouprave Hrvatski sabor donosi većinom glasova svih zastupnika."

37 Iz prihvaćenog monističkog koncepta i hijerarhijske strukture propisane člankom 141. Ustava Republike Hrvatske proizlazi: „Prvo, da je Konvencija za pravni poredak Republike Hrvatske njegov sastavni dio iako je međunarodni pravni akt. Drugo, da je ona u hijerarhijskoj strukturi pravnih propisa, doduše, ispod Ustava Republike Hrvatske, ali iznad zakona (uključivo i ustavnih zakona za promjenu Ustava), čime je dobila status 'subustavnog ili tzv. kvaziustavnog akta' ... Temeljem takvog položaja Europske konvencije, u pravnom sustavu Republike Hrvatske strankama je omogućeno podnijeti tužbu radi zaštite svojih pojedinačnih ljudskih prava i sloboda za koje smatraju da su povrijeđena, ne samo pozivom na ustavne odredbe, već i na konvencijske ili samo na povredu konvencijskih odredbi." Vidjeti rad Arlović, M., „Ustavnosudski aktivizam i europski pravni standardi“, Zbornik radova PFS, Split, br. 1/2014. g., str. 16 . 
- Zakon o zaštiti osobnih podataka (Narodne novine br. 103/03., 118/06., 41/08., 130/11. i 106/02.);

- Zakon o pravu na pristup informacijama (Narodne novine br. 25/13. pročišćeni tekst i 85/15.) i

- Zakon o Hrvatskoj radioteleviziji (Narodne novine br. 25/03., 137/10. i 76/12.).

Za potrebe ovog rada navest ću neke od najvažnijih odredbi iz navedenih organskih zakona, koje su po mom mišljenju važne jer su mjerodavne za razumijevanje pojma, sadržaja i obilježja prava na slobodu izražavanja s jedne strane, a s druge, ovisno o pravnoj prirodi konkretnog slučaja, kao mjerodavno pravo za postupanje Ustavnog suda Republike Hrvatske odnosno ESLJP-a u pružanju sudske zaštite.

Tako Zakon o medijima u člancima 3., 4. i 7. propisuje:

\section{„Članak 3.}

(1) Jamči se sloboda izražavanja i sloboda medija.

(2) Sloboda medija obuhvaća osobito: slobodu izražavanja mišljenja, neovisnost medija, slobodu prikupljanja, istraživanja, objavljivanja i raspačavanja informacija u cilju informiranja javnosti; pluralizam i raznovrsnost medija, slobodu protoka informacija i otvorenosti medija za različita mišljenja, uvjerenja i za raznolike sadržaje, dostupnost javnim informacijama, uvažavanje zaštite ljudske osobnosti, privatnosti i dostojanstva, slobodu osnivanja pravnih osoba za obavljanje djelatnosti javnoga informiranja, tiskanja i raspačavanja tiska i drugih medija iz zemlje i inozemstva, proizvodnju i objavljivanje radijskog i televizijskog programa, kao i drugih elektroničkih medija, autonomnost urednika, novinara i ostalih autora programskih sadržaja u skladu s pravilima struke.

(3) Slobode medija dopušteno je ograničiti samo kada je i koliko je to nužno u demokratskom društvu radi interesa nacionalne sigurnosti, teritorijalne cjelovitosti ili javnoga reda i mira, sprječavanja nereda ili kažnjivih djela, zaštite zdravlja i morala, zaštite ugleda ili prava drugih, sprječavanja odavanja povjerljivih informacija ili radi očuvanja autoriteta i nepristranosti sudbene vlasti samo na način propisan zakonom.

(4) Zabranjeno je prenošenjem programskih sadržaja u medijima poticati ili veličati nacionalnu, rasnu, vjersku, spolnu ili drugu neravnopravnost ili neravnopravnost na temelju spolne orijentacije, kao i ideološke i državne tvorevine nastale na takvim osnovama, te izazivati nacionalno, rasno, vjersko, spolno ili drugo neprijateljstvo ili nesnošljivost, neprijateljstvo ili nesnošljivost na temelju spolne orijentacije, poticati nasilje i rat. 


\section{Članak 4.}

(1) Nitko nema pravo prisilom ili zloporabom položaja utjecati na programski sadržaj medija, ni na bilo koji drugi način nezakonito ograničavati slobodu medija.

(2) O povredama slobode izražavanja i slobode medija odlučuje sud.“

\section{„Članak 7.}

1) Svaka osoba ima pravo na zaštitu privatnosti, dostojanstva, ugleda i časti.

(2) Osoba koja obavlja javnu službu ili dužnost ima pravo na zaštitu privatnosti, osim u slučajevima koji su u vezi s javnom službom ili dužnosti koju osoba obavlja.

(3) Osoba koja svojim izjavama, ponašanjem i drugim djelima u vezi s njezinim osobnim ili obiteljskim životom sama privlači pozornost javnosti ne može zahtijevati istu razinu zaštite privatnosti kao drugi građani.“

Iz Zakona o javnom priopćavanju za ovu priliku posebice izdvajam odredbe članaka 3. i 6. koji glase:

\section{“Članak 3.}

(1) Jamči se sloboda javnoga priopćavanja.

(2) Sloboda javnoga priopćavanja obuhvaća osobito slobodu izražavanja misli, slobodu prikupljanja, istraživanja, objavljivanja i širenja informacija, slobodu tiskanja i raspačavanja tiska i drugih javnih glasila, te proizvodnje i emitiranja radijskoga i televizijskoga programa, slobodu primanja ideja i informacija, kao i slobodu osnivanja pravnih osoba za obavljanje djelatnosti javnoga priopćavanja.

$$
(\ldots)^{\text {“ }}
$$

\section{„,̌́lanak 6.}

(1) Svaka osoba ima pravo na zaštitu privatnosti, dostojanstva, ugleda i časti.

(2) Javne osobe imaju pravo na zaštitu privatnosti, osim u slučajevima koji su u svezi s njihovim javnim životom.

(3) Ne može se na jednaka prava glede zaštite privatnosti pozivati osoba koja svojim izjavama, ponašanjem i drugim djelima u svezi s njezinim osobnim ili obiteljskim životom sama privlači pozornost javnosti.“

Zakon o Hrvatskoj radioteleviziji pored inih sadrži i odredbe koje se odnose na njezine dužnosti u ostvarivanju sadržaja prava na slobodu izražavanja, te na osnovi za poštovanje razmjernosti u njezinoj realizaciji 
između javnog i privatnog interesa. To je osobito vidljivo iz sadržaja članka 6., stavka 1. i članka 7., stavka 1.

\section{„Članak 6.}

(1) U ostvarivanju programa, HRT je dužan:

- promicati nacionalne interese, pridonositi poštivanju i promicanju temeljnih ljudskih prava i sloboda, domoljublju, toleranciji, razumijevanju i poštivanju različitosti, demokratskih vrednota i institucija, civilnog društva, te unapređenju kulture javnoga dijaloga,

- poštivati privatnost, dostojanstvo, ugled i čast čovjeka i temeljna prava i slobode drugih, a osobito djece i mladih, kao i starijih i nemoćnih osoba.

\section{Članak 7.}

(1) HRT je dužan:

- trajno, istinito, cjelovito, nepristrano i pravodobno informirati javnost o činjenicama, događajima i pojavama u zemlji i inozemstvu od javnog interesa,

- poštivati i poticati pluralizam političkih, religijskih, svjetonazorskih i drugih ideja te omogućiti javnosti da bude upoznata s tim idejama; HRT ne smije u svojim programima zastupati stajališta ili interese pojedine političke stranke, kao ni bilo koja druga pojedinačna politička, religijska, svjetonazorska i druga stajališta ili interese,

(...)

- prije objavljivanja provjeriti izvor i sadržaj informacija, u skladu s priznatim profesionalnim standardima neovisnog novinarstva,

- odjeljivati informacije i komentare te jasno označavati komentare kao osobno mišljenje autora.

\section{$(\ldots)^{\text {“ }}$}

Sukladno glavi IV. člancima 16. i 17. Zakona o Hrvatskoj radioteleviziji uređuje se javnost i samostalnost njezinog rada. Tako se npr. već u članku 16. stavku 1. propisuje:

„U svom djelovanju HRT promiče javne vrijednosti i interese, uvažava interese javnosti te za svoje djelovanje odgovara javnosti.“

Samo pitanje pristupa informacijama novinarima i medijima radi ostvarivanja prava na slobodu izvještavanja kao sastavnog dijela prava na slobodu izražavanja uređuje se u Republici Hrvatskoj Zakonom o pravu na pristup informacijama. 
Međutim, ovaj Zakon ne uređuje pravo na pristup informacijama samo za novinare i medije. On uređuje pravo na pristup informacijama kojima raspolažu javne vlasti i koje moraju biti, u skladu s njim, dostupne svima. Dakle, svim građanima i strancima te pravnim osobama pod jednakim uvjetima, bez ikakve diskriminacije. Načela na kojima se temelji Zakon o pravu na pristup informacijama razrađuju odredbe sadržane u člancima: a) načelo javnosti i slobode pristupa (članak 6.), b) načelo pravodobnosti, potpunosti i točnosti informacija (članak 7.), c) načelo jednakosti (članak 8.), d) načelo raspolaganja informacijama (članak 9.), e) načelo međusobnog poštovanja i suradnje (članak 9.a), f) načelo javnosti i testa razmjernosti (članak 16.), i g) načelo ograničenja prava na pristup informacijama (članak 15.) itd.

Samo ograničavanje prava na pristup informacijama, osim $\mathrm{u}$ prethodno navedenoj odredbi članka 15. Zakona o pristupu informacijama, dodatno je razrađeno u svakom pojedinom organskom zakonu za područja koje on regulira. Tako to pitanje, primjerice, dodatno razrađuje Zakon o zaštiti osobnih podataka, Zakon o tajnosti podataka itd. No, o njima se zbog karaktera ovog rada neću na ovom mjestu posebice baviti.

d.d.) Kad je u pitanju sudska praksa ESLJP-a te Ustavnog suda RH putem njihovih odluka i u njima zauzetim stajalištima bit će više riječi u posebnom poglavlju ovog rada.

\section{O međuodnosu prava na slobodu izražavanja i slobode kao jedne od najviših vrednota ustavnog poretka}

Polazeći od prethodno izloženog ustavnopravnog okvira koji se odnosi na propisivanje i uređivanje prava na slobodu izražavanja, moguće je njihovom analizom utvrditi odnos između tog ustavnog prava i slobode i drugih najviših vrednota ustavnog poretka u Republici Hrvatskoj, njezini subjekti, sadržaj, obilježja, ograničenja, itd.

Sasvim je razvidno, da je pravo na slobodu izražavanja samo jedna od osobnih i političkih sloboda i prava koje ustavotvorac derivira iz Ustavom utvrđenih najviših vrednota ustavnog poretka uključivo, prije svega, slobodu kao jednu od njih.

Dok je sloboda iz članka 3. Ustava jedna od najviših vrednota ustavnog poretka koja je i temelj za njegovo tumačenje, dotle je sloboda na pravo izražavanja jedno od ustavom utvrđeno i zajamčeno subjektivno pravo. Samim time, svakog ovlaštenika kod pravnog reguliranja prava na slobodu izražavanja, uključivo i ustavotvorca, sam Ustav obvezuje da to mora učiniti u skladu s najvišim vrednotama ustavnog poretka. Istovrsna je ustavnopravna pozicija i za sve one koji tumače i primjenjuju to subjektivno pravo neovisno o prirodi mogućeg pravnog spora. Naime, svatko je dužan tumačiti i primjenjivati to ustavno pravo polazeći od temeljnih vrednota ustavnog poretka sadržanih u članku 3. Ustava Republike Hrvatske tako da interpretaciju prava, obveza i odgovornosti sadržanih 
u pravu na slobodu izražavanja tumači sukladno njima, neovisno o tome radi li to u svrhu normativnog cilja (zakonodavac) donoseći zakon kojim razrađuje ostvarivanje tog ustavnog prava ili se u sudskom ili ustavnom sporu rješava o pravima ili ustavnopravnim pitanjima.

Takva pozicija i međuodnos između prava na slobodu izražavanja i slobode kao najviše vrednote proizlazi i iz njezinog mjesta koje joj je namijenio hrvatski ustavotvorac i sukladno tome ga zauzima u hrvatskom Ustavu. Naime, ona je sadržana u članku 38., točki 2. Osnovne i političke slobode i prava, poglavlja III. Zaštita ljudskih prava i temeljnih sloboda, dok je sloboda kao jedna od najviših vrednota ustavnog poretka sadržana u članku 3. poglavlja II. Temeljne odredbe Ustava Republike Hrvatske.

\section{O pravnoj prirodi prava na slobodu izražavanja}

Što se tiče pravne prirode prava na slobodu izražavanja, iz citiranog ustavnopravnog okvira bez sumnje proizlazi da je riječ o ustavnom i konvencijskom utvrđenom i zajamčenom ljudskom pravu i temeljnoj slobodi koju hrvatski ustavotvorac radi njezinog ostvarivanja i zaštite dalje razrađuje u skladu $\mathrm{s}$ ustavnim normama organskih zakona. S obzirom na to da je riječ o ljudskom pravu i slobodi, ono bez sumnje pripada svakom. U tom pogledu je, kao i druga ljudska prava i slobode, univerzalnog, ali nije i ne može biti apsolutnog karaktera. Naprosto stoga što ga je u skladu s Ustavom i Europskom konvencijom propisanim uvjetima i kriterijima moguće ograničiti. ${ }^{38}$ No ta ograničenja se mogu, kako propisuje sam Ustav, učiniti samo zakonom i to privremeno i u skladu s ustavom utvrđenim razlozima (iz članka 16. i 17. Ustava Republike Hrvatske). Pri tome se uvijek mora voditi računa o tome da su ograničenja razmjerna potrebi za ograničenjem u svakom konkretnom slučaju te da su nužna (jer ne postoje druga blaža sredstva) i prihvatljiva u demokratskom društvu i, dakako, da su sukladna pravu. ${ }^{39}$ Nadalje, pravo na slobodu izražavanja kao ustavom utvrđeno i zajamčeno pravo može biti razrađivano kao skup prava, obveza i odgovornosti samo organskim zakonima. ${ }^{40}$ To nedvojbeno upućuje na to da su svi ovlaštenici tog ustavnog prava ravnopravni i jednaki. Naprosto zbog toga što su po sili samog

38 Smatramo da se sloboda kao jedna od najviših vrednota ustavnog poretka ne može ograničiti i da je ona kao vrednota apsolutnog karaktera. To, dakako, ne znači da je njezino tumačenje kod primjene ustava po svom obuhvatu, pa nažalost i sadržaju, uvijek sto posto jednako. Naprosto stoga što njezino, kao i svako tumačenje bilo koje vrednote podliježe subjektivnim slabostima tumača. No, mora se inzistirati da, bar kad je u pitanju provedba i zaštita ustavom utvrđenih i zajamčenih prava, ta odstupanja, ako ih uopće ima, budu takva da ne zadiru u supstancijalni dio subjektivnog ustavom zajamčenog prava. Drugi pokazatelj koji upućuje na zaključak da se sloboda kao vrednota ne može ograničiti te da je, dakle, kao takva apsolutnog karaktera, vezana je uz činjenicu da u hrvatskom ustavno-pravnom poretku postoje $\mathrm{i}$ takva prava na slobodu (slobodu misli, savjesti i vjeroispovijesti) koja se u primjeni ustavnih odredbi o njima ne mogu ograničiti (vidjeti pobliže članak 17., stavak 3. Ustava Republike Hrvatske).

39 Vidjeti već citirane odredbe članka 16. i 17. Ustava Republike Hrvatske (Narodne novine br. 85/10.).

40 Članak 83., stavak 2. Ustava Republike Hrvatske (Narodne novine br. 85/10.). 
Ustava svi jednaki pred zakonom ${ }^{41}$ te ,pred sudovima i drugim državnim i inim tijelima koja imaju javne ovlasti“ ${ }^{42}$ Osim toga, neophodno je ukazati da se po svom sadržaju i obuhvatu radi o složenom i raznovrsnom, a ne jednostavnom pravu. Upravo stoga se i radi o ustavnom pravu koje je neophodno potrebno i važno za ostvarivanje drugih ustavnih sloboda i prava, njegovih vrednota, ali i cjelokupnosti ideala i ciljeva slobodnog demokratskog društva slobodnih ljudi u državi vladavine prave i ustava.

\section{Subjekti i sadržaj prava na slobodu izražavanja}

\section{a) Subjekti}

Ustav Republike Hrvatske izravno (izrijekom) ne govori tko su ovlaštenici subjekti - prava na slobodu izražavanja. On člankom 38., stavkom 1., generalnom klauzulom propisuje: „Jamči se sloboda mišljenja i izražavanja misli“, a u ostalim stavcima istog članka propisuje što ona sadržavaju, čime su ili se mogu ograničiti te pod kojim se uvjetima ostvaruju. S obzirom na generalnu klauzulu, moglo bi se zaključiti da to pravo kao ljudsko pravo pripada svakom. Naprosto zbog toga što ljudska prava i slobode pripadaju svakom ljudskom biću. No, za razliku od navedene odredbe hrvatskog ustava, Europska konvencija u članku 10. jasno određuje da je ovlaštenik ovog prava svatko, propisujući već u prvoj rečenici prvog stavka da „,svatko ima pravo na slobodu izražavanja“. Polazeći od ustavnopravnog položaja Europske konvencije u ustavnom poretku Republike Hrvatske, valja konstatirati da je ovakvom njezinom stipulacijom otklonjena svaka sumnja. Moramo zaključiti da je u ustavnopravnom poretku Hrvatske subjekt prava na slobodu izražavanja svatko. No, pojam svatko, iako je prisutan u ustavnopravnom poretku, ${ }^{43}$ ovdje nije određen, ali jest i mora biti odrediv. Smatramo da su u pravu oni teoretičari i praktičari ${ }^{44}$ koji pojam „svatko“ interpretiraju na način da on obuhvaća:

a) svaku fizičku osobu (dakle državljanina Republike Hrvatske, ali i strance, pogotovo koji su pod njezinom jurisdikcijom) te

b) svaku pravnu osobu.

Slijedom iskazanoga, smatram se ovlaštenim zaključiti da je pravo na slobodu izražavanja pravo koje je, kako pojedinačno tako i kolektivno, s aspekta njegovog prava na ostvarivanje, pogotovo ako ga se promatra u sklopu cjeline njegovog sadržajnog obuhvata, pravo koje pripada svim fizičkim i pravnim osobama,

${ }^{41}$ Člankom 14., stavkom 2. Ustava Republike Hrvatske propisano je: „Svi su pred zakonom jednaki“.

42 Članak 26. Ustava Republike Hrvatske propisuje: „Svi su državljani Republike Hrvatske i stranci jednaki pred sudovima i drugim državnim i inim tijelima koja imaju javne ovlasti““.

43 Vidjeti npr. odredbe članka 14., 21. stavka 1., 24. stavka 3., 25. stavka 4., 26., 28., 29. stavka 1., 35., 37. stavka 1., 46., 55. stavka 1., 59., 70. stavke 1. i 3. Ustava Republike Hrvatske.

44 Tako npr. J. Crnić, vidjeti njegov rad Komentar Ustavnog zakona o Ustavnom sudu Republike Hrvatske, Zagreb, 2002. g., str. 169. ili Smerdel, B., Ustavno uređenje europske Hrvatske, Zagreb, 2013. g., str. 320-321. 
državljanima i strancima te pravnim osobama pod jurisdikcijom Republike Hrvatske.

\section{b) Sadržaj}

Pravo na slobodu izražavanja Ustav Republike Hrvatske naziva slobodom mišljenja i izražavanja misli. Ono je zajamčeno i to kao proces (sloboda mišljenja) i kao konkretna radnja izražavanja misli. ${ }^{45}$

Sadržajno kao sloboda izražavanja misli obuhvaća:

a) slobodu izražavanja misli,

b) slobodu govora i javnog nastupa,

c) slobodu tiska i drugih sredstava priopćavanja,

d) slobodu osnivanja svih ustanova javnog priopćavanja. ${ }^{46}$

Polazeći od stipulacije članka 38., stavaka 3., 4. i 5. Ustava, smatram potrebnim primijetiti da je ustavom zajamčena sloboda mišljenja i izražavanja misli iz stavka 1., te njezin sadržaj iz stavka 2. tog članka, na neizravan način dopunjavana pravima i sadržajima koji su s njom u supstancijalnoj vezi i utječu na njezino ostvarenje. To su: a) zabrana cenzure, b) ustavno jamstvo prava na pristup informacijama, c) razlozi za ograničenje prava na pristup informacijama koji konkretiziraju u ovim ustavno-pravnim slučajevima ustavnu osnovu iz članka 16., stavka 1. u pogledu mogućnosti zakonskog ograničavanja ljudskih prava i sloboda te d) ustavno jamstvo prava na ispravak svakomu komu je javnom viješću povrijeđeno Ustavom i zakonom utvrđeno pravo. ${ }^{47}$

Zabranu cenzure valja tumačiti kao zabranu „oficijelnog nadzora državnih tijela nad sredstvima javnog priopćavanja“, koja bi, kada bi bila dopuštena, dovodila to toga da sredstva javnog priopćavanja ,mogu objavljivati samo ono što nadležni cenzori odobre“" ${ }^{48}$ Međutim, iako je formalna cenzura silom same ustavne norme zabranjena, prof. dr. B. Smerdel s pravom upozorava na „opasnost autocenzure, gdje ljudi u medijima, svjesni prilika u kojima djeluju i rizika povezanih sa slobodnim izvješćivanjem, sami strogo vode računa da ne povrijede osjećaje vlasti i njezinih dužnosnika“. ${ }^{49}$ Naime, autocenzura kao instrument koji otežava ili u cijelosti sprečava ostvarivanje prava na slobodu izražavanja

45 Vidi članak 38., stavak 1. Ustava Republike Hrvatske (Narodne novine br. 85/10.).

46 Interesantno je primijetiti da se ustavni sadržaj koji obuhvaća pravo na slobodu izražavanja misli iz članka 38. Ustava Republike Hrvatske značajno detaljizira i proširuje organskim zakonima koji bi trebali razrađivati ovo pravo. Osobito je u tom pogledu ilustrativan članak 3. Zakona o medijima. On, prvo, drugačije u svom stavku 1. daje jamstvo propisujući: „Jamči se sloboda izražavanja i sloboda medija“, dok Ustav jamči ,slobodu mišljenja i izražavanja misli“. Zapravo Ustav nigdje ne daje ustavno jamstvo slobodi medija na način kako to propisuje Zakon o medijima. Nadalje u stavku 2. istog članka Zakon o medijima daje daleko obuhvatniji sadržaj slobode medija nego što se vidi iz navedenog članka 38 . Ustava. Dakako, to ne mora samo iz tog razloga biti neustavno.

47 Vidjeti članak 38., stavak 5. Ustava Republike Hrvatske (Narodne novine br. 85/10.).

48 Smerdel, B., Ustavno uređenje europske Hrvatske, Zagreb, 2013. g., str. 320.

49 Ibidem. 
putem objave ideja i misli u medijima može biti čak teža u pojedinim oblicima i konkretnim situacijama od same oficijelne cenzure. Na tu je okolnost upozoravao već Tocqueville, izlažući tezu da se ljudi boje slobodno govoriti ne samo zbog straha od kazni već i zbog pritiska članova svoje zajednice. Nije nepoznata situacija da se pojedinac kad iznosi, i putem medija objavljuje, nepopularne ideje i misli, može suočiti s prijezirom pa i s različitim oblicima prijetnji i pritisaka koji mogu ići sve do zlostavljanja njega i njegovih članova obitelji od članova svoje uže i šire zajednice. Primjerice, nisu nepoznati primjeri takvog postupanja prema idejama i mislima koje izražavaju i putem medija objavljuju nositelji liberalnih i/ili ateističkih ideja u zemljama s velikim brojem vjernika ili npr. manjinskih (rodnih, vjerskih, nacionalnih, jezičnih i dr.) skupina.

Pravo na pristup informacijama koje imaju tijela javne vlasti kao pravo zajamčeno Ustavom u Republici Hrvatskoj propisano je, kako smo to već istaknuli, 2010. godine provođenjem četvrte promjene Ustava Republike Hrvatske. Ta je pravna regulacija proizašla iz potrebe pravnog uređivanja ideje po kojoj javnost, ali i pojedinac, imaju pravo s jedne strane znati kako javne vlasti upravljaju društvom, odnosno kako ispunjavaju povjerene im obveze da ostvaruju vlast u ime birača kao ravnopravne zajednice državljana. S druge strane, otvaraju li svojim odlukama javne vlasti prostor za ostvarivanje ljudskih prava i temeljnih sloboda svakog pojedinca te s treće strane, donose li odluke u skladu s ustavnopravnim poretkom što omogućuje realizaciju njegovih temeljnih vrednota i time doprinosi realizaciji tradicija, ciljeva $i$ vrednota na kojima se temelji i kojima stremi demokratsko društvo vladavine prava u ustavnoj državi. Naime, samo zajednica u kojoj, uz ustavnopravnu, postoji i stvarna mogućnost ostvarivanja prava na slobodu izražavanja ideja i misli slobodna je i demokratska zajednica. To pravilo mora biti važeće i poštovano čak i onda kada se s izraženim idejama i mislima ne slažemo. Naprosto zbog toga što je pravo na slobodu izražavanja temelj demokratskog, političkog i socijalno-kulturnog sustava i zato se ostvarenje ovog prava mora omogućiti, a njega zaštititi i u slučajevima, da parafraziram Voltairea, kada se duboko s govornikom i njegovim mišljenjem ne slažemo.

Samo pravo na pristup informacijama koje imaju tijela javne vlasti ustavotvorac je uredio pod utjecajem s jedne strane stvarnih potreba u demokratskom društvu, a s druge strane zbog poteškoća u tumačenju dotadašnje ustavne odredbe, ${ }^{50}$ osobito uslijed njezine nedovoljne obuhvatnosti koju su sve više zahtijevale modernizacija $\mathrm{i}$ internetizacija suvremenog medijskog prostora, te s treće strane zbog potrebe da se u odnosu na ova pitanja provedu u konkretnim sporovima utvrđena i zauzeta stajališta Ustavnog suda Republike Hrvatske i ESLJP-a.

Osnovni smisao novog stavka 4. članka 38. Ustava Republike Hrvatske bio je u postizanju legitimnog cilja koji treba omogućiti svim građanima, uključivo i strancima te pravnim osobama, da pod jednakim uvjetima imaju pravo pristupa

50 Naime, krug pitanja koji su proizlazili iz takvih društvenih odnosa do unošenja novog stavka 4. nakon 4. promjene Ustava Republike Hrvatske 2010. godine rješavao se pozivom na članak 38 ., stavak 3. Ustava Republike Hrvatske. 
informacijama kojima raspolažu tijela javne vlasti. Pri tom se mora uočiti i zaštititi javni interes koji može zahtijevati da se određenim informacijama može zakonom ograničiti pristup. Poštujući načelo iskazano u ustavnom tekstu da „ograničenja prava na pristup informacijama moraju biti razmjerna naravi potrebe za ograničenjem u svakom pojedinom slučaju te nužna u slobodnom i demokratskom društvu, a propisuju se zakonom" “. ${ }^{51}$ Uistinu, ona su i propisana člancima 15. i 16. Zakona o pravu na pristup informacijama. No, uz ta ograničenja koja proizlaze iz Zakona o pravu na pristup informacijama, još jednom podsjećam da se pravo na slobodu izražavanja misli, kao i svako drugo ljudsko pravo i temeljna sloboda, mogu zakonom ograničiti kada se za to steknu ustavom propisani razlozi iz članka 16., odnosno kada nastupe situacije i uvjeti koje propisuje članak 17. Ustava Republike Hrvatske. Po tome se, u načelu, to ljudsko pravo i sloboda ne razlikuju od drugih ljudskih prava i sloboda. No, ono što u pravilu čini specifikum prava na slobodu izražavanja misli (ideja i misli, op. A.) u odnosu na druga ljudska prava i temeljne slobode jest ustavnopravna činjenica da je u odnosu na to pravo sam Ustav Republike Hrvatske u članku 39. propisao: „Zabranjeno je i kažnjivo svako pozivanje ili poticanje na rat ili uporabu nasilja, na nacionalnu, rasnu ili vjersku mržnju ili bilo koji oblik nesnošljivosti“. Po mom mišljenju, nema dvojbe da se ta ustavna zabrana odnosi izravno na takvu mogućnost korištenja prava na slobodu izražavanja.

Samo pravo na ispravak koje je Ustavom zajamčeno „svakomu komu je javnom viješću povrijeđeno Ustavom i zakonom utvrđeno pravo“, prihvaća i priznaje pravo medijima na grešku s jedne strane, ali s druge strane utvrđuje pravo na pokretanje pitanja odgovornosti novinara i/ili institucije čijom je informacijom povrijeđeno pravo fizičke i/ili pravne, domaće ili strane osobe.

Polazeći od svega prethodno iskazanoga, smatram da je moguće zaključiti da se u slučaju prava na slobodu izražavanja radi o tzv. izvedenom pravnom pojmu koji se u pravu naziva pravna konstrukcija. ${ }^{52}$ Prethodno je već rečeno da je pravo na slobodu izražavanja, uostalom kao i druga prava na različite slobode koje se odnose na ljudska prava i temeljne slobode, derivirano iz slobode kao vrednote i to u sklopu hrvatskog ustavnopravnog poretka one slobode koja je zajedno s drugima jedna od najviših vrednota ustavnog poretka i temelj za tumačenje samog Ustava Republike Hrvatske. No, nakon prethodno provedene analize sadržaja koji obuhvaća pravo na slobodu izražavanja, sasvim je vidljivo da je ono izvedeno i obuhvaća čitav niz nižih pravnih pojmova i da iz njih uzima sve ono što im je zajedničko i od toga u svojoj konstrukciji sadrži sve što je tim pojmovima zajedničko. Glavna ideja iz izvedenih pojmova koje nazivamo pravnom konstrukcijom sadržana je upravo u tome što ona s jedne strane obuhvaća sve ono što je nižim pravnim pojmovima zajedničko, ali s druge strane što se njezinim tumačenjem može dublje i cjelovitije sagledati bit svakog od pojedinačnih pojmova (pravne norme) te u konačnici osigurati njihovo bolje povezivanje i razumijevanje.

51 Vidjeti pobliže drugu rečenicu stavka 4. članka 38. Ustava Republike Hrvatske.

52 Pojam ,pravna konstrukcija“ preuzet je iz Pravne enciklopedije, Beograd, 1979. g., str. 1039. 
Tako, teleološkim tumačenjem pravne konstrukcije dedukcijom možemo izvoditi određene logičke posljedice koje se primjenjuju i na niže pojmove, iako nužno nisu sadržani u njima. Na taj način se uz pomoć pravne konstrukcije i putem nje nižim pravnim pojmovima dodaju sadržaji koje oni prije nisu imali. ${ }^{53}$

Zbog toga je pravna konstrukcija izuzetno podesna za tzv. evolutivno tumačenje, odnosno aktivističkog pristupa u zaštiti ljudskih prava i temeljnih sloboda, kojim je moguće uz formalnu osigurati i njihovu realnu - stvarnu zaštitu. ${ }^{54}$ Naprosto jer se tumačenje pravne konstrukcije temelji kako na tumačenju nižih pojmova - prava koje ono obuhvaća, tako i najviših vrednota ustavnog poretka iz kojih je također derivirana. Idealni primjer izvedenog pojma kao pravne konstrukcije jest upravo ustavom zajamčeno i propisano pravo na slobodu mišljenja i izražavanje misli, i to onakve kakvu je hrvatski ustavotvorac ugradio člankom 38. Ustava u ustavopravni poredak Republike Hrvatske.

Razumljivo je stoga samo po sebi da je jako teško, gotovo neizvedivo, definirati takve pojmove putem jedinstvene sintetičke definicije. Zbog toga se u njezinom određenju, u pravilu pristupa deskripcijom njezinih sadržaja i karakteristika. Upravo sam tako i sâm postupio, kao što je vidljivo iz prethodnog dijela rada.

\section{EUROPSKI SUD ZA LJUDSKA PRAVA I USTAVNI SUD REPUBLIKE HRVATSKE U ZAŠTITI PRAVA NA SLOBODU IZRAŽAVANJA}

\section{Uvod}

Pravo na slobodu izražavanja iz članka 10. Europske konvencije, odnosno onakvo kako ga propisuje npr. hrvatski ustavnopravni poredak, za razvoj demokracije, uvažavanja i ostvarivanje brojnih drugih ljudskih i manjinskih prava i sloboda iznimno je važno i ima dalekosežni značaj. Ono je po svojoj pravnoj prirodi i sadržaju s jedne strane širokog obuhvata, s druge strane složeno od drugih prava i sloboda i s treće pod jednakim uvjetima pripada svim fizičkim i pravnim osobama. Iz svih tih razloga ESLJP je nastojao na osnovi mnogih predmeta koje je rješavao izgraditi i utvrditi kriterije za tumačenje članka 10., dakako polazeći od osnovnih načela Europske konvencije kao cjeline. Temeljem njih, on je, rješavajući konkretne predmete, izgradio i iskazao općeobvezujuća stajališta, koja obvezuju same države članice, sudionike spora predmet koji se rješavaju, i države članice koje prihvaćaju njegovu sudsku nadležnost. Kako su presude i u njima zauzeta stajališta ESLJP-a obvezatna za sve članice, to su one ne samo od njih prihvaćena i poštovana, već i korištena kako u izgradnji svojih ustavno-pravnih poredaka, tako, osobito u postupcima pred njihovim sudbenim tijelima, poglavito onima koja u svom djelokrugu imaju obvezu postupanja i odlučivanja o zaštiti

53 Šire o pravnoj konstrukciji vidjeti u Pravnoj enciklopediji, Beograd, 1979. g., str. 1039.

54 Više o sudskom aktivizmu vidjeti u knjizi prof. dr. Petra Bačića Konstitucionalizam i sudski aktivizam, Split, 2010. g., te npr. u autorovu radu: „Ustavnosudski aktivizam i europski pravni standardi“, objavljenom u Zborniku radova Pravnog fakulteta, Split, br. 1/2014. g., str. 1-27. 
ljudskih prava i temeljnih sloboda. Kod nas je to, kao i u gotovo svim drugim zemljama Europe, Ustavni sud Republike Hrvatske. ${ }^{55}$

Uzgred budi rečeno, obveza poštovanja i provođenja odluka i u njima zauzetih stajališta ESLJP-a proizlazi i iz članka 46. Europske konvencije za sve njezine članice ugovornice. Osim toga, sam ESLJP rekao je da njegove presude „zapravo služe ne samo da se riješe ini slučajevi koji su podneseni pred Sud, već puno šire da razlože (elucidate), očuvaju i razviju pravila koja je ustanovila Europska konvencija“. ${ }^{56}$ Pored formalne obveze, i ovako iskazani cilj ESLJP-a bio je motiv i osnova Ustavnom sudu Republike Hrvatske da prihvati stajalište koje se temelji na utvrđenju da presude ESLJP-a prelaze granice pojedinačnih slučajeva koje on in concreto rješava. Ustavni sud Republike Hrvatske prihvatio je tzv. ,interpretativni autoritet" presuda ESLJP-a, neovisno o državi protiv koje je presuda donesena. Na taj je način Ustavni sud Republike Hrvatske prihvatio ulogu Europskog suda „kao kreatora ustavnih standarda“ s jedne strane, a s druge njegovu interpretaciju Europske konvencije „kao ustavnog instrumenta europskog javnog prava“ ${ }^{57} \mathrm{U}$ tom svjetlu, s pravom ističe predsjednica Ustavnog suda Republike Hrvatske prof. dr. sc. Jasna Omejec da „,po naravi stvari nije moguće govoriti o poštovanju Konvencije, odnosno o primjeni prakse Europskog suda ako se država ugovornica ograničava samo na presude koje taj sud donosi u odnosu na nju samu. Europski ustavni standardi, naime, proizlaze iz ukupnosti jurisprudencije tog suda. “58

Prihvaćanje i provođenje prakse ESLJP-a od Ustavnog suda Republike Hrvatske i njeno usklađivanje i preuzimanje u svoju praksu možda je najzornije moguće prikazati upravo na jurisprudenciji koju su provodila ova dva suda u rješavanju sporova koji su u svojoj osnovi imali spor u vezi s pravom na slobodu izražavanja.

55 Takvo postupanje Ustavnog suda Republike Hrvatske razvidno je primjerice u odluci broj: U-III-1142/2013 od 1. prosinca 2014. U toj se odluci hrvatski Ustavni sud više puta pozivao na odluke ESLJP-a, uz izričitu potvrdu da prihvaća zauzeta stajališta tog suda u tim predmetima i primjenjuje ih u svim gore navedenim predmetima. Riječ je o predmetima Guja protiv Moldavije iz 2012. te Balenović protiv Hrvatske iz 2009. Uzgred rečeno, u tim je predmetima ESLJP zauzeo stajališta u vezi s konvencijskim pravom na slobodu izražavanja iz članka 10. koja korespondiraju s njegovim stajalištima koja ću nastavno $\mathrm{u}$ ovom radu izložiti. S jedne strane ta su stajališta i Ustavnog suda Republike Hrvatske koje je on $\mathrm{u}$ vezi s pravom na slobodu izražavanja misli i tiska zauzeo u svojoj Odluci broj: U-III-2823/2003 od 23. studenoga 2005., o kojoj će također u ovom radu kasnije biti riječi.

56 Odluka ESLJP-a u predmetu Irska protiv Ujedinjenog Kraljevstva od 18. siječnja 1978., zahtjev br. $5310 / 71$.

57 Šire vidjeti kod Arlović, M., „Ustavnosudski aktivizam i europski pravni standardi“, Zbornik radova Pravnog fakulteta u Splitu, br. 1/2014. g., str. 17.

58 Omejec, J., „Načela i sredstva za priznavanje interpretativnog autoriteta presuda protiv drugih država - iskustvo Ustavnog suda Hrvatske“, referat podnesen na Konferenciji u Skoplju, Republika Makedonija, 1.-2. listopada 2010. koju je organiziralo Ministarstvo pravde Republike Makedonije u suradnji s Venecijanskom komisijom, str. 8. (privatna arhiva autora). 


\section{O praksi ESLJP-a u zaštiti prava na slobodu izražavanja}

Zbog pravne prirode koja proizlazi iz prava na slobodu izražavanja kao pravne konstrukcije s jedne, a s druge strane zbog njezinog sadržaja i uloge u tumačenju i razumijevanju drugih vrednota, načela i standarda ${ }^{59}$ koji su osnova za ustroj i izgradnju suvremenog demokratskog društva, ESLJP se vrlo brzo susreo s potrebom da utvrdi što on razumijeva pod slobodom izražavanja te kriterije za tumačenje članka 10. Europske konvencije kojim je ona propisana. Tako je već 1976. godine u predmetu Handyside protiv Ujedinjenog Kraljevstva izrazio svoje mišljenje što razumijeva pod izrazom pravo na slobodu izražavanja i koja je njegova uloga u demokratskom društvu, ustvrdivši: „Sloboda izražavanja predstavlja jedan od bitnih temelja takvog društva, jedan od bitnih uvjeta za njegov napredak, kao i za razvoj svakog čovjeka ... Ona se odnosi ne samo na 'informacije' ili 'ideje' koje primamo s naklonošću ili smatramo neškodljivim ili nevažnim, već i na one koje su uvredljive, šokantne ili uznemiravajuće za državu ili bilo koji dio pučanstva. To su zahtjevi što pluralizma, snošljivosti i širokogrudnosti bez kojih nema demokratskog društva." 60

Od tog slučaja pa do danas, dakle tijekom nepunih daljnjih četrdeset godina svoga djelovanja pa i postupanja i rješavanja predmeta koji u svojoj osnovi imaju pravo na slobodu izražavanja, ESLJP izgradio je čitav niz kriterija i stajališta o tome kako postupati i rješavati pojedine takve sporove koji se javljaju u društvenim odnosima.

Sumarno iskazano, prema pravnoj naravi pojedinih sporova, njih je gospođa Donna Gomien u svojoj knjizi Europska konvencija o ljudskim pravima, proučavajući jurisprudenciju ESLJP-a koji u svojoj osnovi imaju spor iz članka 10. Konvencije u vezi s pravom na slobodu izražavanja, sistematizirala kako slijedi. ${ }^{61}$

Utvrdila je da je ESLJP izgradio i prihvatio hijerarhiju vrijednosti kojima služi članak 10. Europske konvencije, tj. pravo na slobodu izražavanja. „Unutar te hijerarhije, komentiranje javnih događaja od javnih osoba ili medija predstavlja najzaštićeniji oblik izražavanja, dok su promidžbene poruke najmanje zaštićene.“

Polazeći od tako utvrđene hijerarhije, ESLJP za slobodu izražavanja u kontekstu javne rasprave ,propisuje veliku vrijednost slobodi izražavanja izabranih članova zakonodavnog tijela smatrajući da se njima mora pružiti obuhvatna zaštita izražavanja o pitanjima od interesa za njihove birače i javnosti općenito“. Međutim, ,javne i političke osobe moraju biti spremne na kritiku medija“. Ta kritika se mora

59 Kao potvrdu te teze vidjeti primjerice zauzeto mišljenje ESLJP-a u predmetu Handyside protiv Ujedinjenog Kraljevstva (1976. g.), kod Gomien, Donna, Europska konvencija o ljudskim pravima, Zagreb, 2007. g., str. 167-168.

60 Gomien, D., Europska konvencija o ljudskim pravima, Zagreb, 2007. g., str. 168.

${ }_{61}$ Uz navedenu knjigu autorice Gomien, D., čitatelja posebice upućujem i na knjigu predsjednice Ustavnog suda Republike Hrvatske, prof. dr. sc. Jasne Omejec: Konvencija za zaštitu ljudskih prava $i$ temeljnih sloboda u praksi Europskog suda za ljudska prava - Strasbourški acquis, Zagreb, 2013. g., napose stranice 1237-1263, zatim knjigu Vesne Batistić Kos: Pozitivne obveze prema Europskoj konvenciji za zaštitu ljudskih prava i temeljnih sloboda, Zagreb, 2012. g., posebice str. 265-267. 
odvijati u okviru prihvatljivih granica. No, ,granice prihvatljive kritike sukladno tome šire su s obzirom na političare ... negoli s obzirom na privatne osobe. Za razliku od privatnih osoba, političari znaju da su neizbježno pod udarom novinara i javnosti koji pomno ispituju svaku njihovu riječ i postupak. Članak 10. stavak 2. omogućuje zaštitu ugleda drugih ... što se odnosi i na političare ... ali u ovakvim slučajevima zahtjevi takve zaštite trebaju biti u ravnoteži s važnošću interesa javne rasprave o političkim pitanjima.“”

Nadalje, ESLJP je u istim predmetima u pogledu dokazivanja istinitosti navoda istaknuo sljedeće stajalište: „Osobito pomno treba razlikovati činjenice od vrijednosnih sudova. Postojanje činjenica može se dokazati, dok istinitost vrijednosnih sudova ne podliježe dokazivanju ..."

Drugo, ESLJP je zauzeo „stav da zaštita bilo kojeg pojedinca od kritike isključivo na temelju njegove funkcije ili statusa postavlja preširoku povlasticu koja nije sukladna s članskom 10.“62 Nadalje, u drugim predmetima, „Sud je zauzeo stav da ova tvrdnja“ (,kad je država tvrdila da je osuda bila opravdana u vidu borbe protiv terorizma“, op. A.) „ne dopušta državi neopravdano ograničavanje prava javnosti na informiranje o kontroverznim stavovima tako da vrši pritisak na medije putem kaznenog prava“". ${ }^{63}$

Treće, „neki od najvažnijih predmeta temeljem članka 10. Konvencije odnose se na slobodu izražavanja novinara i medija u kontekstu rasprave o pitanjima od općeg interesa za javnost, kako u političkom tako i u onom koji nije politički“. U vezi s tim problemom, ESLJP je, rješavajući predmet Sunday Times protiv Ujedinjenog Kraljevstva (br. 1.) (1979.), zauzeo „stav da javnost općenito ima pravo biti informirana o tom predmetu, čak kada se o činjenicama i pitanjima o kojima je riječ vodi sudski postupak. Podvukao je nekoliko čimbenika koji su bili važni za njegovu odluku, na primjer, široku i bezuvjetnu zabranu privremene mjere, umjerenost zabranjenog članka, duljinu i sporost sudskog postupka i izvansudskih nagodbi, te široku javnu raspravu o temi iz članka. Tim je sud postavio visoku razinu zaštite tiska utemeljujući zaštitu na pretpostavci da je pravni interes najbolje zaštićen kada je osigurano da sve raspoložive informacije budu dane na uvid javnosti." ${ }^{4}$

Isto je tako ESLJP utvrdio stav „,da stupanj u kojem je neki pojedinac ušao u javnu arenu ili javnu raspravu služi za određivanje stupnja snošljivosti što ga on mora imati prema kritici (Nislon i Johnsen protiv Norveške /1999./)“.

62 Gomien, D., Europska konvencija o ljudskim pravima, Zagreb, 2007. g., str. 172.

63 Ibidem, str. 173.

64 Ibidem, str. 174-177. 
Četvrto, u odnosu na tzv. pozitivne obveze države ${ }^{65}$ prema članku 10., ,Sud je postavio načela da država može imati pozitivnu obvezu zaštititi novinare i novinske nakladnike od zastrašivanja, zlostavljanja i nasilničkog ponašanja“. Tako npr. „u predmetu Özgür Gündem protiv Turske (2000.), Sud je utvrdio povredu članka 10. jer državna vlast nije pružila zaštitu novinama koje su bile meta terorističkih napada. Sud je naveo da država mora jamčiti slobodu izražavanja između ostalog tako da osigura siguran ambijent za njezino vršenje. S obzirom na to da su novinari i distributeri novina bili ozlijeđeni, zlostavljani, pa čak ubijeni, a državna vlast nije odgovorila na zahtjeve da pruži zaštitu i provedu istragu o tim zločinima, Sud je utvrdio povredu članka 10.“"(u tom predmetu op. A.). ${ }^{66}$

Peto, uz zauzete stavove koje je ESLJP zauzeo u predmetima vezanima uz pitanje dozvola za emitiranje, sloboda promidžbenog oglašavanja i sloboda umjetničkog izražavanja na temelju prava na slobodu izražavanja temeljem članka 10. Konvencije koji se nastavno obrađuje u navedenoj knjizi, ${ }^{67}$ smatram važnijim za ovaj rad ukazati na stajališta ESLJP-a o pitanjima vezanima uz dužnosti i odgovornosti pojedinaca prema članku 10., te na temelju njega o pravu na primanje i širenje informacija.

ESLJP smatra opravdano da ,prema članku 10.1 'svatko' ima pravo na slobodu izražavanja, uključujući i slobodu primanja i širenja informacija i ideja. Međutim, prema članku 10.2 vršenje ovih sloboda donosi određene dužnosti i odgovornosti pojedinaca ..." Doduše, iako, „Europski sud za ljudska prava općenito favorozira

65 Bivši predsjednik ESLJP-a, Jean-Paul Costa, u svom predavanju o međuodnosu različitih načela koja definiraju interpretativne metode ESLJP-a prema pozitivnim obvezama, objašnjava na sljedeći način: „Koncept afirmativnih dužnosti država Konvencije je ujedno i eksplicitno i implicitno sadržan u tekstu Konvencije. Članak 1., koji je krucijalan, sadrži opću obvezu država da 'osiguravaju svakome' prava koja slijede iz članaka 2. do 14. Na tu se odredbu oslanja Sud u razvoju svoje pravne prakse o pozitivnim obvezama koje proizlaze iz članaka 2. i 3. Ta dva članka izražavaju najtemeljnije vrijednosti ljudske civilizacije ... Stoga je u ta dva područja pravna praksa Suda otišla najdalje u razjašnjavanju pozitivnih obveza država (...) te u jasnim i konkretnim odrednicama, identificirala standarde i modalitete ponašanja država. Razvoj pozitivnih obveza od strane Suda se također temelji na brizi za učinkovitost svakog jamstva Konvencije, koja mora, kao što se to često kaže, biti praktična i učinkovita, a ne teoretska i iluzorna. Ta briga prožima čitav konvencijski sustav ... Želim naglasiti oprez kojim Europski sud pristupa utvrđivanju pozitivne obveze prema članku 8. On zauzima različite pristupe takvim zahtjevima, važući prirodu i intenzitet miješanja. Obavljajući tu vježbu ravnoteže, Sud nastoji locirati pravičnu ravnotežu između suprotstavljenih interesa pojedinaca i ovih društava u cjelini. Državi se daje sloboda prosudbe koja je općenito šira nego kad se radi o negativnim obvezama, gdje se miješanje mora prikazati kao nužno ... Nadalje, dinamična priroda prava znači da se, neovisno o faktičnim različitostima između slučajeva, točka ravnoteže može pomaknuti s vremenom bliže poziciji pojedinca." Njegovo predavanje održano na Sveučilištu u Leidenu 20. svibnja 2008. navedeno je prema Vesna Batistić Kos, Pozitivne obveze prema Europskoj konvenciji za zaštitu ljudskih prava i temeljnih sloboda, Zagreb, 2012. g., str. 17-18. Inače, V. B. Kos u ovoj svojoj knjizi polazi od toga da se ,pozitivne obveze u najvećem broju slučajeva zasnivaju na konvencijskom izričaju koji govori o obvezi 'zaštite' i 'osiguranja' jamčenih prava pojedinaca“. Istovremeno, po njenom mišljenju, ,negativna je obveza ona kojom se od države zahtijeva da se suzdrži od miješanja, odnosno da poštuje (respect) ljudska prava“. Stoga, ,dok negativna obveza od državnih tijela traži nečinjenje u smislu djelovanja njenih tijela kojima se potvrđuje ljudska prava, pozitivna obveza bit će povrijeđena ukoliko su državna tijela ostala pasivna u slučaju nastojanja povrede od strane treće osobe“. Vidjeti pobliže str. 22-25 navedene knjige.

66 Isto kao fusnota 62 , str. 182.

67 Ibiden, vidjeti str. 187-189. 
novinare i privatne osobe pred javnim i političkim osobama“, on je ,priznavao kako država može ograničiti slobodu političkog izražavanja državnih vlasti ili njenih službenika, ne utvrdivši povredu članka $10 “ .68$

Kada je u pitanju pravo na primanje i širenje informacija, ESLJP je u predmetu Leander protiv Švedske (1987.), polazeći od članka 10. Europske konvencije, zauzeo stav da on ,u osnovi zabranjuje državnoj vlasti da ograniči nekoj osobi primanje informacija koju drugi žele ili možda su spremni mu dati. Članak 10. ne dodjeljuje pojedincu u okolnostima poput ovih u ovom predmetu, pravo pristupa podacima o njegovom osobnom položaju, niti nameću obvezu državnim vlastima da mu takvu informaciju dadu“ itd. ${ }^{69}$

Neka od navedenih stajališta ESLJP-a primjenjivao je i na predmete iz Republike Hrvatske koje je u svojoj praksi rješavao.

Tako je u predmetu Europapress Holding d.o.o. protiv Hrvatske ${ }^{70}$ utvrdio da nije došlo do povrede članka 10. Europske konvencije u vezi s postupkom u povodu tužbe za klevetu koju je bivši ministar financija pokrenuo pred domaćim sudovima protiv tvrtke podnositelja radi objave članka u svom tjedniku da je navedeni ministar u sobi Vlade za novinare uperio pištolj u jednu od novinarki.

Nadalje, u predmetu Stojanović protiv Hrvatske, ${ }^{71}$ koji se odnosi na postupak po tužbi za klevetu bivšeg ministra zdravlja koji se vodio pred domaćim sudovima u kojem je gospodin Stojanović bio tužena osoba. Postupak je vođen nakon objave dvaju članaka u tjednim novinama u kojima je gospodin Stojanović komentirao rad ministra. Domaći su sudovi navedene izjave ocijenili klevetničkima pa je gospodinu Stojanoviću presuđeno da ministru naknadi štetu prouzročenu takvim tvrdnjama. ESLJP je u svojoj odluci za dvije od spornih izjava utvrdio da je riječ o pravu na slobodu izražavanja i da su domaći sudovi svojom presudom temeljenoj na njima povrijedili pravo gospodina Stojanovića na slobodu izražavanja. Stoga je ESLJP prihvatio prijedlog za zaštitu prava, ukinuo osporenu odluku domaćeg suda te sve vratio na ponovni postupak smatrajući da ponovljeni postupak predstavlja najprikladniji način ispravka posljedica prouzročenih povredom članka 10 . Europske konvencije.

U trećem predmetu Rujak protiv Hrvatske, ${ }^{72}$ ESLJP utvrdio je da vrijeđanje i omalovažavanje drugog te da govor mržnje nisu zaštićeni člankom 10. Europske konvencije, jer ne predstavljaju pravo na slobodu izražavanja. Sam predmet se odnosio na ročnog vojnika, koji je u svojoj postrojbi vrijeđao druge vojnike na nacionalnoj osnovi zbog čega je u postupcima pred domaćim sudovima bio kažnjen nakon provedbe kaznenog postupka. Uzgred budi rečeno, radilo se o vojniku pripadniku srpske nacionalne manjine.

\footnotetext{
68 Ibid., str. 187-189.

69 Ibid., str. 190.

70 Presuda od 22. listopada 2009. g., zahtjev br. 25333/06.

71 Presuda od 9. prosinca 2010. g., zahtjev br. 23160/09.

72 Presuda od 2. listopada 2012. g., zahtjev br. 57942/10.
} 


\section{O praksi Ustavnog suda Republike Hrvatske u zaštiti prava na slobodu izražavanja misli}

Temeljem ustavnopravnog okvira kojim je uređeno pravo na slobodu izražavanja u Republici Hrvatskoj s jedne strane te prakse i zauzetih stajališta ESLJP-a s druge strane, Ustavni sud Republike Hrvatske je u postupcima u predmetima u kojima se spor vodio zbog povrede prava na slobodu izražavanja izgradio svoju praksu i kriterije za postupanje u takvim slučajevima te u svojim odlukama i njihovim obrazloženjima zauzeo općeobvezujuća stajališta. ${ }^{73}$

Najjezgrovitija i cjelovita načelna stajališta o značenju, dosezima a time i ograničenjima slobode izražavanja Ustavni sud Republike Hrvatske zauzeo je u svojoj Odluci broj: U-III-2723/2003 od 23. studenoga 2005. (Narodne novine br. 147/05.). ${ }^{74}$

Ta načelna stajališta glase:

„Sloboda izražavanja predstavlja jedan od bitnih temelja svakog demokratskog društva. Njena zaštita je od posebne važnosti kad se radi o tisku jer je zadaća tiska, pored ostaloga, objava informacija od javnog značenja. Međutim, sloboda objavljivanja informacija u tisku ograničena je zaštitom ugleda i prava drugih osoba. Stoga je važno utvrditi okolnosti u kojima državna tijela poduzimaju mjere koje bi mogle utjecati na djelovanje tiska u slučajevima koji su od legitimnog javnog interesa.

Sloboda izražavanja misli ne odnosi se samo na izražavanje i objavljivanje podataka i ideja koje imaju pozitivan stav, već i na objavljivanje informacija koje bi mogle imati negativan odjek u javnosti. Međutim, sloboda izražavanja nije apsolutna, već podliježe određenim ograničenjima, čak i u odnosu na napise u tisku, koji se tiču informacija od javnog interesa. Ustavno jamstvo slobodnog izražavanja sadrži obveze i odgovornosti, koje se odnose i na tisak. Te obveze i odgovornosti dolaze do izražaja i kad, kao u ovom predmetu, dođe do povređivanja ugleda državnog dužnosnika. Upravo radi postojanja tih obveza i odgovornosti od strane onih koji se koriste svojim pravom na slobodu izražavanja, tisak je prilikom iznošenja informacija od javnog interesa dužan postupati u dobroj vjeri kako bi pružio vjerodostojne informacije u skladu s novinarskom etikom.

Pri ocjeni je li došlo do povrede slobode izražavanja potrebno je sagledati svaki pojedini slučaj u svjetlu svih okolnosti, uključujući sadržaj spornih navoda, kao i kontekst u kojemu su ti navodi izrečeni. Osobito je potrebno utvrditi jesu li mjere poduzete radi ograničenja slobode izražavanja razmjerne legitimnom cilju koji

73 O općeobveznosti odluka i rješenja te u njihovim obrazloženjima zauzetih i iskazanih stajališta vidjeti odredbe članka 31. i 77. Ustavnog zakona o Ustavnom sudu Republike Hrvatske (Narodne novine br. 49/02. - pročišćeni tekst).

74 Inače u supstancijalnom smislu riječ je o ustavnosudskom postupku koji je svojom ustavnom tužbom pokrenuo Europapress Holding d.o.o. iz Zagreba, a koji je nezadovoljan ishodom postupka pred Ustavnim sudom RH kasnije pokrenuo postupak ESLJP-om. Taj je sud s istovjetnim rezultatom po podnositelja odlučio kao Ustavni sud Republike Hrvatske svojom presudom od 22. listopada 2009. g., zahtjev br. $2533 / 06$. 
se tim ograničenjem želi postići. Zaštita državnih dužnosnika od uznemiravanja, međutim, mora uvažavati pravo i interes tiska na slobodno izvještavanje te mu omogućiti slobodno iznošenje informacija od javnog interesa.

\section{(...)}

Budući da prednik podnositelja ustavne tužbe, u konkretnom slučaju, nije udovoljio svojoj obvezi provjere informacija prije njihovog objavljivanja, što je, s obzirom na svoju djelatnost bio dužan učiniti, a radilo se o informacijama koje su naštetile ugledu i časti druge osobe, Ustavni sud smatra da su mjere poduzete radi ograničenja slobode izražavanja prednika podnositelja ustavne tužbe bile potrebne i opravdane.

U odnosu na dosuđenu naknadu neimovinske štete za povredu ugleda druge osobe, Ustavni sud ističe da sudovi imaju diskrecijsko pravo pri odlučivanju o visini te naknade za pretrpljene duševne boli oštećene osobe, imajući pritom u vidu okolnosti svakog slučaja. Međutim, i odlukom suda o visini te naknade može se narušiti načelo razmjernosti između težine miješanja sudova u slobodu izražavanja i važnosti interesa koji se ograničavanjem te slobode želi postići.

Ustavni sud je utvrdio da je mjera poduzeta radi zaštite ugleda druge osobe, odnosno dosuđivanje naknade štete u navedenom iznosu, razmjerna težini povrede ugleda te osobe, kao i težini miješanja sudova u slobodu izražavanja, koje je tom mjerom učinjeno. S obzirom na to da se podnositelj u svom djelovanju, kao novinska kuća, nije pridržavao odredbi koje propisuje ZJP (Zakon o javnom priopćavanju - op. A.), prema mišljenju Ustavnog suda, radilo se o napisu koji je narušio ugled druge osobe te umanjio povjerenje javnosti u tu osobu, kao nositelja funkcija državne vlasti.

Stoga je utvrđeno da je mjera, poduzeta u konkretnom slučaju, radi ograničenja slobode tiska, u svojoj cjelokupnosti razmjerna postizanju opravdanog cilja - zaštiti ugleda druge osobe te da osporenim sudskim odlukama nije došlo do ograničenja slobode ili prava podnositelja ..."

Izgrađeni i utvrđeni kriteriji u tumačenju osnovnih načela te samog članka 10. Europske konvencije i na njima u konkretnim predmetima zauzetih načelnih stajališta o značenju, dosezima i ograničenjima slobode izražavanja te kod utvrđivanja njezinih povreda od ESLJP-a i temeljne slobode u svojojustavnopravnoj praksi u istovrsnim predmetima kao svoje prihvaća i primjenjuje u okolnostima konkretnog slučaja (ne mijenjajući njihov supstancijalni značaj) Ustavni sud Republike Hrvatske. Međutim, treba istaknuti da je u svojoj ustavnopravnoj praksi i hrvatski Ustavni sud izgradio i izgrađuje u istovrsnim predmetima vlastitu praksu koja je inherentna potrebi za zaštitom prava na slobodu izražavanja s jedne strane, a s druge strane koja korespondira s praksom ESLJP-a. Ustavni sud Republike Hrvatske može danas reći da je njegova praksa u ovoj vrsti predmeta u načelu prihvatljiva i za ESLJP. Ona, možda, nije takva da bi utjecala na promjenu već zauzetih stajališta ESLJP-a, ili na zauzimanje novih, ali u svakom slučaju može se reći da je potvrđena od samog ESLJP-a što je za njegov rad od iznimne 
važnosti. Još je važnije da su s odlukama u predmetima vezanima uz zaštitu prava na slobodu izražavanja zadovoljni podnositelji u Republici Hrvatskoj.

Praksa ESLJP-a i Ustavnog suda Republike Hrvatske pokazuje da su zauzeta načelna stajališta u ovdje navedenim predmetima višekratno u istim istovrsnim slučajevima potvrđena i primijenjena u njihovim novim predmetima vezanima uz zaštitu prava na slobodu izražavanja. ${ }^{75} \mathrm{~S}$ druge strane, ta njihova stajališta možda nisu bila presudna, ali ih je svakako imao u vidu hrvatski ustavotvorac kada je u četvrtoj promjeni Ustava Republike Hrvatske provedenoj 2010., novim stavkom 4. dopunio članak 38. Ustava i time otklonio u dijelu prisutnu ustavnopravnu prazninu u ustavnom uređenju prava na slobodu mišljenja i izražavanja misli.

Znatniji (veći) utjecaj zauzeta stajališta u predmetima za zaštitu prava na slobodu izražavanja ESLJP-a i Ustavnog suda Republike Hrvatske imali su na zakonodavno postupanje i odlučivanje Hrvatskog sabora kod donošenja zakona kojim se uređivalo to područje.

Zbog značaja u pravnom uređivanju, a posebice u postupcima za pružanje sudske i ustavnosudske zaštite prava na slobodu izražavanja gore zauzetih načelnih stajališta u kojima je kroz prikaz prakse ESLJP-a i Ustavnog suda Republike Hrvatske bilo riječi, još jednom ću, taksativno (barem najznačajnija od njih) nabrojati u jezgrovitom i sadržajnom sažetom iskazu, bez njihova posebnog elaboriranja, objašnjavanja i opisivanja, kako slijedi.

\section{Sažeci iz prakse ESLJP-a i Ustavnog suda Republike Hrvatske o} zaštiti prava na slobodu izražavanja (neka od najznačajnijih načelnih stajališta)

- Pravo na slobodu izražavanja od iznimnog je značaja za ostvarenje i razvoj demokracije, ideala, slobode, pravde i vladavine prava u demokratskom društvu koje je ustrojeno i pravno uređeno u modernoj ustavnoj državi.

- Ostvarivanje prava na slobodu izražavanja bitna je pretpostavka(nezamjenjiv uvjet) za ostvarivanje i zaštitu drugih ljudskih prava i temeljnih sloboda.

- Pravo na slobodu izražavanja jest složeno pravo koje je s jedne strane izvedeno iz ideala slobode kao najviše vrijednosti i cilja modernog društva, a s druge strane (kao i pravna konstrukcija - op. A.) obuhvaća niz drugih prava i sloboda. Iako, kao takvo, ono nije apsolutnog, već je relativnog karaktera.

- Pravo na slobodu izražavanja putem prava na slobodu informiranja od strane novinara i medija u davanju, primanju i širenju informacija mora se omogućiti najednak način i kada su te informacije ugodne, korisne i neškodljive, i kada su one uvredljive, uznemiravajuće, pa i kada su škodljive.

75 Vidjeti pobliže npr. presudu ESLJP-a (uz prethodno navedene) u predmetima: Guja protiv Moldavije (GC), zahtjev br. 14277/04, presuda iz 2012. g., Jacubowski protiv Njemačke, presuda od 23. lipnja 1994. $\S 25$, Serija A br. 291-A) ili Karsai protiv Mađarske, presuda od 1. prosinca 2009., zahtjev br. 5380/07. Vidi također odluke Ustavnog suda Republike Hrvatske u predmetima: U-III-1142/2013 od 1. prosinca 2014., U-III-4057/2003 od 12. listopada 2006., U-III-152/2006 od 24. siječnja 2007., U-III-2108/2012 od 8. svibnja 2014., U-III-3946/2011 od 11. prosinca 2014., U-III-929/2012 od 11. ožujka 2015. itd. 
- Granice u kojima se ostvaraju prava na slobodu izražavanja s obzirom na prihvatljivost javne kritike moraju biti:

- šire u odnosu na političare i druge javne osobe nego za privatne osobe,

- šire u odnosu na državne dužnosnike, službenike i namještenike kad se one odnose na poslove i svojstvo koje te osobe imaju nego za privatne pravne osobe,

- u ravnoteži s predmetom rasprave o političkim i/ili drugim javnim pitanjima s očekivanim, razumnim, opravdanim i legitimnim javnim interesima.

- U hijerarhiji stupnja ostvarivosti i zaštiti prava na slobodu izražavanja najviše mjesto na hijerarhijskoj ljestvici mora pripadati neposredno izabranim predstavnicima zakonodavne i drugih vidova javne vlasti, s tim da im se sveobuhvatna zaštita prije svega mora pružiti kad se njezino ostvarivanje odnosi na probleme i pitanja koji su od interesa za njihove birače i sveukupnu javnost općenito. Slična pozicija pripada i političkim stankama te udrugama u odnosu na stupanj i oblik njihove uloge u predstavljanju i zaštiti interesa njihovih članova, simpatizera i javnosti ukupno u pogledu predstavljanja i ostvarivanja njihovih ideja i programa u višestranačkom demokratskom društvu.

- Javne i političke osobe moraju biti spremne na kritiku novinara i medija, i to sa šireg i obuhvatnijeg aspekta nego privatne osobe, ali povezano uz njihove javne funkcije i dužnosti te izvršavanje poslova zbog njihove realizacije. Napose zbog višeg stupnja zainteresiranosti šire javnosti.

- Svako uključivanje pojedinca u javnu arenu ili javnu raspravu samo po sebi služi za određivanje kriterija snošljivosti koju on mora imati prema kritici kao sredstvu ostvarivanja prava na slobodu izražavanja.

- Zaštita pojedinaca od kritike koja se temelji isključivo na njegovoj funkciji ili dužnosti odnosno statusa u društvu prevelika je povlastica i nije u skladu s pravom na slobodu izražavanja.

- Neprihvatljivo je ostvarivanje prava na slobodu izražavanja kad se ono ostvaruje izražavanjem ideja i misli, informacijama i njihovim širenjem na osobito ponižavajući i uvredljiv način. Upotrebu takvog jezika u ostvarivanju prava na slobodu izražavanja ne opravdava ni javni interes ni bilo koja stvar od općeg značaja.

- U reguliranju, provedbi i zaštiti prava na slobodu izražavanja država ima, uz negativne, i pozitivne ovlasti i dužnosti.

- Pravo na slobodu izražavanja obuhvaća pravo osobe da prima informacije koje joj drugi žele ili su joj, možda, spremni dati. Načelno, državnoj vlasti zabranjeno je ograničiti primanje takvih informacija.

- Ograničavanje prava na slobodu izražavanja kojim se ograničava pravo 
javnosti na informacije o kontroverznim stavovima nedopustivo je na način da se na medije vrši pritisak putem kaznenog prava.

- Svako ograničenje prava na slobodu izražavanja mora biti propisano zakonom ili pravnim propisom zakonske snage (uredbe sa zakonskom snagom) u skladu s ustavnim i konvencijskim pravom utvrđenim i propisanim uvjetima i kriterijima.

- Ustavom zajamčeno pravo na pristup informacijama kojima raspolažu tijela javne vlasti može se ograničiti zakonom, ali to ograničenje mora biti razmjerno naravi potrebe za ograničenjem u svakom pojedinom slučaju te nužno u slobodnom i demokratskom društvu.

- U rješavanju sporova proizašlih iz ostvarivanja prava na slobodu izražavanja putem prava novinara, novina i drugih medija da informiraju javnost o pitanjima i problemima od općeg i javnog interesa te o djelovanju javne vlasti, u njihovom ograničavanju uvijek je potrebno provesti testove opravdanosti (vaganje) s ciljem određivanja kojem od interesa dati prednost.

- Kod dokazivanja povrede prava na slobodu izražavanja moraju se razlikovati činjenice od vrijednosnih sudova jer se činjenice mogu dokazati dok istinitost vrijednosnih sudova ne podliježe dokazivanju.

- U zaštiti prava na slobodu izražavanja država mora osigurati pristup sudu i sudsku zaštitu.

- U svim slučajevima izricanja kazni i drugih mjera potrebno je ispitati njihovu razmjernost težini povrede prava na slobodu izražavanja u konkretnom slučaju. Vlada, upravne i sudbene vlasti moraju dokazati opravdanost izrečenih kazni i drugih mjera u svakom pojedinom slučaju, poglavito ako su im u istoj stvari bila na raspolaganju blaža sredstva.

- Priroda, težina i opseg kazne, te relevantnost i dostatnost odlučivanja domaćih sudova predstavljaju značajna pitanja za ocjenu razmjernosti, potrebe i opravdanosti njihovog miješanja. ${ }^{76}$

\section{ZAKLJUČNA RAZMATRANJA}

Nema dvojbe da su u pravu svi oni koji ističu da je sloboda najviši ideal slobodarske teorijske misli i demokratske prakse te da je kao takva jedna od najviših vrednota ljudskog društva. Međutim, ona kao vrednota kroz vrijeme i prostor doživljava svoje preobrazbe ovisno o stupnju spoznajnog i ukupnog društvenog razvitka, pa u krajnjoj liniji i od dominantnog kulturološkog ethosa društvene i nacionalne zajednice u kojoj se iskazuje i razmatra. Štoviše, ona kao

76 Uzgred budi rečeno, neka od navedenih načelnih stajališta iskazana su i ponovno potvrđena od ESLJP-a u predmetima u kojima je postupao, a dolaze iz ovih (jugoistočnih prostora). Ilustracije radi vidjeti presude: Lepojić protiv Srbije, presuda od 6. studenoga 2007., zahtjev br. 13909/05, Filipović protiv Srbije, presuda od 20. studenoga 2007., zahtjev br. $27935 / 05$, te presude u predmetima Koprivica protiv Crne Gore, presuda od 22. studenoga 2011. te Šabanović protiv Crne Gore, presuda od 31. svibnja 2011. itd. 
vrednota nužno podliježe tumačenju i vrednovanju, i teško je iz njezinog ad hoc prevladavajućeg poimanja u danom društvu izbjeći subjektivnu komponentu koja je proizašla iz nesavršenstva pa i ideološke i/ili političke i kulturološke obojenosti, odnosno pripadnosti tumača čije je tumačenje u društvu prihvaćeno kao prevladavajuće i dominantno. Zbog toga sloboda kao vrednota nije najpodesnija da se u ustavnopravnom poretku normira kao subjektivno pravo. Međutim, ona kao društvena vrednota koja čini jednu od osnova na kojoj počiva i u skladu s kojom se razvija ukupna društvena zajednica jest jedna od ustavnopravnih vrednota na kojoj s jedne strane počiva cjelokupno ustavnopravno uređenje društva i njegov ustroj kao države, a s druge kao vrednota iz koje se deriviraju mnoga subjektivna prava, i slobode kao prava, a ponajprije ona koja u modernom konstitucionalističkom pristupu čine jednu od bitnih komponenti za konstitucionalizaciju moderne, slobodne i demokratske društvene i državne zajednice, ljudskih i manjinskih prava i temeljnih sloboda, vladavine prava i ustava podjele i ograničene vlasti u kojoj sve sastavnice vlasti međusobno surađuju i uzajamno se provjeravaju.

Jedna od možda najznačajnijih sloboda kao prava iz slobode kao vrednote jest pravo na slobodu mišljenja i slobodu izražavanja misli. Riječ je o takvom pravu na slobodu postojanje, realizacija i zaštita kojeg je nezaobilazni uvjet za ostvarivanje svake slobode od pojedinca preko obitelji do društva u cjelini u demokratskom društvu. Zbog toga je pravo na slobodu mišljenja i izražavanja misli s jedne strane bitna pretpostavka za ostvarivanje drugih ljudskih prava i temeljnih sloboda, a $\mathrm{s}$ druge strane ugaoni kamen ostvarivanja razvoja i zaštite demokracije.

Pravo na slobodu mišljenja i izražavanja misli uz to što je izvedeno pravo iz slobode kao vrednote, istovremeno je po svojoj prirodi pravo koje kroz svoj sadržaj obuhvaća na izravan i/ili neizravan način čitav niz drugih prava $\mathrm{i}$ sloboda (npr. slobodu govora, javnog istupa, slobodu tiska i drugih sredstava priopćavanja, slobodu osnivanja svih ustanova javnog priopćavanja, pravo na pristup informacijama kojima raspolažu tijela javne vlasti itd.). U tom smislu može se reći da je pravo na slobodu izražavanja u ustavnom poretku po svojoj pravnoj naravi najbliže tzv. pravnoj konstrukciji.

Zbog svog značaja za sve fizičke i pravne osobe u društvu ono nije i ne može biti apsolutnog, već je relativnog karaktera. Relativnost karaktera prava na slobodu izražavanja možda je najlakše i najjednostavnije objasniti činjenicom da je ono u konkretnom slučaju za svakoga pojedinca, sukladno s načelom jednakosti i ravnopravnosti, ograničeno istim takvim pravom drugog pojedinca odnosno druge fizičke i/ili pravne osobe. Upravo se stoga kod ograničavanja prava na slobodu uvijek mora voditi računa o tome da njegovo ograničenje bude razmjerno naravi potrebe za ograničenjem, da je nužno i opravdano u svakom konkretnom slučaju u slobodnom i demokratskom društvu, te da se može i mora provesti samo zakonom. 
Zbog svog značenja za realizaciju slobode kao vrednote u zajednici s drugim najvišim vrednotama demokratskog društva, a u krajnjoj liniji za realizaciju i ukupnu djelotvornost ustavnopravnog poretka u regulaciji, realizaciji i zaštiti prava na slobodu mišljenja i slobodu izražavanja misli, država ima i pozitivne i negativne obveze.

Pozitivne se obveze prije svega ogledaju i sagledavaju kroz propisivanje „jamstva“, „zaštite“, „osiguranja“, „obveze javne vlasti“ itd. koja se odnose na obvezu državnih tijela (odnosno tijela javne vlasti) da omoguće ostvarivanje i zaštitu prava na slobodu izražavanja njihovim ovlaštenicima. Dakle, ona od državnih tijela traže aktivnu djelatnu obvezu (činjenje), dok negativne obveze države u odnosu na ostvarivanje prava na slobodu izražavanja traže od države (i svih tijela javne vlasti) trpljenje odnosno nečinjenje, jer bi svojom činidbom u konkretnom slučaju mogla dovesti do povrede prava na slobodu izražavanja. Razumljivo je da se pozitivna i/ili negativna uloga države u odnosu na ostvarivanje prava na slobodu izražavanja utvrđuje odnosno ocjenjuje u svakom konkretnom slučaju ponaosob, posebice kada je to nužno radi toga da se utvrdi jesu li javna tijela povrijedila prava na slobodu izražavanja.

Za povredu prava na slobodu izražavanja, kao i svih drugih prava i sloboda koje ono obuhvaća, u ustavnopravnom poretku ustavne i demokratske države vladavine prava pored inih obligatorno je osigurana sudska zaštita.

No, kako je pravo na slobodu izražavanja mišljenja jedno od najznačajnijih ljudskih prava i temeljnih sloboda, za njegovu zaštitu osigurana je (nakon iscrpljenosti tzv. drugog propisanog pravnog puta koji je osigurava) ustavnosudska zaštita te u supsidijarnom postupku i sudska zaštita ESLJP-a.

Kroz svoju dosadašnju sudsku praksu ESLJP te Ustavni sud Republike Hrvatske utvrdili su i usvojili kriterije za tumačenje prava na slobodu izražavanja u odnosu kako je ono ustavnopravno regulirano u ustavnopravnom poretku Republike Hrvatske, uključujući i konvencijsko pravo kao sastavni dio tog poretka.

Rješavajući konkretne predmete, ESLJP i Ustavni sud Republike Hrvatske utvrdili su i zauzeli načelna stajališta o značenju, dosezima te ograničenjima slobode izražavanja kojih se drže i primjenjuju ih u konkretnim postupcima, ali su ona istodobno općeobvezna za sve kad postupaju i rješavaju o zaštiti prava na slobodu izražavanja misli u istim odnosno istovrsnim slučajevima.

Na kraju je za ustavnopravni poredak Republike Hrvatske važno istaći da iz odredbe članka 39. Ustava Republike Hrvatske proizlazi da je svako korištenje prava na slobodu izražavanja koje bi bilo usmjereno na pozivanje ili poticanje na rat ili uporabu nasilja, nacionalnu, rasnu ili vjersku mržnju ili bilo koji oblik nesnošljivosti - zabranjeno i kažnjavano. 


\section{LITERATURA}

1. Alaburić, Vesna: Sloboda izražavanja u Republici Hrvatskoj, Priručnik o slobodi javne riječi (Coliver, Sandra, Darbshire, Helen i Bošnjak, Mario, ur.), Article 19, London, i Press Data, Zagreb, 1998.

2. Anić Vladimir: Rječnik hrvatskog jezika, treće prošireno izdanje, Zagreb, 2000.

3. Arlović, Mato: „Ustavnosudski aktivizam i europski pravni standardi“, Zbornik radova Pravnog fakulteta u Splitu br. 1/2014.

4. Arlović, Mato: „Ustav Republike Hrvatske osnova društva ravnopravnih ljudi, sigurnosti i stabilnosti“, referat podnesen na Međunarodnoj konferenciji Ustav: jedinstvo ljudi, stabilnosti i prosperiteta u povodu dvadesete godišnjice Ustava Republike Kazahstan održanoj u Astani 28. i 29. kolovoza 2015.

5. Arlović, Mato: „Pravo nacionalnih manjina“, doktorski rad, objavljen na Pravnom Fakultetu u Osijeku, 2012.

6. Bačić, Arsen: Ustavno pravo Republike Hrvatske, Praktikum, Split, 2006.

7. Bačić, Petar: Konstitucionalizam $i$ sudski aktivizam, Split, Pravni fakultet Sveučilišta, 2010.

8. Batistić Kos, Vesna: „Pozitivne obveze prema Europskoj konvenciji za zaštitu ljudskih prava i temeljnih sloboda“, Zagreb, Narodne novine, 2012.

9. Caramani, Daniele: Komparativna politika, Zagreb: Fakultet političkih znanosti, Centar za cjeloživotno obrazovanje, 2013.

10. Costa, Jan Paul: predavanje na temu „Međuodnos različitih načela koja definiraju interpretativne metode Suda prema pozitivnim obvezama“, održano na Sveučilištu Liedenu 20. svibnja 2008., u Batistić Kos, Vesna: Pozitivne obveze prema Europskoj konvenciji za zaštitu ljudskih prava i temeljnih sloboda, Zagreb, 2012.

11. Crnić, Jadranko: „Komentar Ustavnog zakona o Ustavnom sudu Republike Hrvatske“, Zagreb, Narodne novine, 2002.

12. Đorđević, Jovan: Politički sistemi, Beograd, Savremena administracija, 1977.

13. Friedman, Milton: Kapitalizam i sloboda, Zagreb, Školska knjiga, 1992.

14. Gomien, Donna: Europska konvencija o ljudskim pravima, Zagreb, 2007.

15. Mill, John Stuart: O slobodi, Zagreb, 1918.

16. Ljubić, Dubravko: „Ustavni pojmovi prava, slobode, jamstva, načela, mogućnosti i zabrane“, Hrvatska pravna revija, Zagreb, lipanj 2011.

17. Norris, Pippa: „Politička komunikacija“, u Caramani, D. Komparativna politika, Zagreb, 2013.

18. Omejec, Jasna: Konvencija za zaštitu ljudskih prava i temeljnih sloboda u praksi Europskog suda za ljudska prava - Strasbourški acquis, Zagreb, Novi informator, 2013.

19. Omejec, Jasna: „Način i sredstva za priznavanje interpretacijskog autoriteta presuda protiv drugih država - iskustvo Ustavnog suda Hrvatske“, referat na Konferenciji u Skoplju, Republika Makedonija, koju je organiziralo Ministarstvo pravde u suradnji s Venecijanskom komisijom, 1.-2. listopada 2010. (privatna arhiva autora).

20. Politička enciklopedija, Beograd, 1975. 
21. Pravna enciklopedija, Beograd, 1979.

22. Pravni leksikon, Zagreb, 2007.

23. Rodin, Siniša: „Pravo na slobodno razvijanje osobnosti u njemačkom ustavnom pravu“, Zbornik PFZ, br. 1-2/1997.

24. Smerdel, Branko: „Ustavno uređenje europske Hrvatske“, Zagreb, Narodne novine, 2013.

25. Smerdel, Branko: „Zadaće pravne znanosti i pravničke struke na dvadesetu obljetnicu 'Božićnog Ustava' - ustavni izbori i procesi ostvarivanja najviših ustavnih vrednota i strateških ciljeva Republike Hrvatske“, Zbornik HAZU Dvadeseta obljetnica Ustava Republike Hrvatske, Zagreb, 2011.

26. Smerdel, Branko i Sokol, Smiljko: Ustavno pravo, Zagreb, Pravni fakultet, 2006.

27. Sweet, Allec Stone: „Uslovi i sudska vlast“, u Caramani, D. Komparativna politika, Zagreb, 2013.

28. Weber, Max: Vlast i politika, Zagreb, Jesenski i Turk, 2013.

29. Visković, Nikola: Pojam prava, Split, Birotehnika, 1976.

30. Vrban, Dušan: Država i pravo, Zagreb, Golden marketing, 2002.

31. Ustav Republike Hrvatske (Narodne novine br. 85/10. - pročišćeni tekst).

32. Ustavni zakon o Ustavnom sudu Republike Hrvatske (Narodne novine br. 49/02. - pročišćeni tekst).

33. Europska konvencija za zaštitu ljudskih prava i temeljnih sloboda (Narodne novine - Međunarodni ugovor, br. 18/97., 6/99. i 8/99.).

34. Zakon o medijima (Narodne novine br. 59/04., 84/11. i 84/13.).

35. Zakon o javnom priopćavanju (Narodne novine br. 69/03. - pročišćeni tekst).

36. Zakon o pravu na pristup informacijama (Narodne novine br. 25/13. i 85/15. pročišćeni tekst).

37. Zakon o Hrvatskoj radioteleviziji (Narodne novine br. 25/03., 137/10. i 76/12.).

38. Zakon o zaštiti osobnih podataka (Narodne novine br. 103/03., 118/06., 41/08., 130/11. i 106/12.).

39. Odluke Europskog suda za ljudska prava navedene u tekstu rada.

40. Odluke Ustavnog suda Republike Hrvatske navedene u tekstu rada.

41. Odluke Ustavnog suda Republike Crne Gore navedene u tekstu rada.

42. Odluke Ustavnog suda Republike Srbije navedene u tekstu rada. 


\section{RIGHT TO FREEDOM OF SPEECH AND EXPRESSION (constitutional framework andConstitutional Court practice in the Republic of Croatia}

This paper analyses the connection and inter relationship of freedom as the highest value of constitutional order of the Republic of Croatia and the highest ideal of contemporary democracy and constitutional state with the right to freedom of speech and expression. By analysing that interrelationship, the intention to confirm the thesis that the right to freedom of speech and expression is just one (albeit very important)human right and fundamental freedom arises. It has been extracted from freedoms as the highest value and as one which is always returned to in such a way that affects the scope and content of it being achieved in relation to the imagined ideal of freedom and the given reality. The right to freedom of speech and expression is analysed as just one of the fundamental supports for building a democratic society of rule of law and Constitution. In this context, the function of the indispensable condition for achieving other human rights and fundamental freedoms is also analysed. Furthermore, it is considered as a right within which, through its content, includes a range of other rights and freedoms. It should be considered from a theoretical viewpoint as a so called legal construction. This paper analyses the constitutional legal framework in the Republic of Croatia related to the right to freedom of speech and expression. In that analysis, particular attention is given to the subject, content and characteristics of the right to freedom of speech and expression and the practice of European Court of Human Rights and the Constitutional Court of the Republic of Croatia which protect this right.

Key words: freedom, freedom of speech and expression, constitutional legal framework, principle viewpoints, human rights and freedoms 